\title{
Teacher Competencies and Qualifications for Support Services in Special Education
}

\section{Institutions*}

\author{
Firat KESER $^{* *}$ Arzu TANRIVERDI***
}

- Received: 30.12.2020 • Accepted: 23.04.2021 • Online First: 23.04.2021

\begin{abstract}
The purpose of this research is to discuss teacher competencies and qualifications in special education schools, special education classes, counseling and research centers (CRC), and special education rehabilitation centers (SERC) for providing educational support services (ESS) to individuals with special needs (SEN). This research was designed as qualitative research, and focus group interviews were chosen as a data collection technique. Sixty-two teachers working in CRCs, SERCs, special education schools, and classes participated in the research. A descriptive analysis method, which is used in qualitative research methods, was used in order to analyze the research data. The findings of the research were examined under six themes. It was found that the teachers (including special education teachers) had difficulty in teaching skills and concepts, interfering problem behaviors, providing sexual education with students and parent training, communicating with families in their native language, planning a student's individual education planning (IEP), assessing students formally and informally, and adapting to technology for the goals of IEP. Furthermore, in an inclusive education system, teachers do not/cannot offer support services to those with diverse languages, religions, cultures, and sexual orientations. On the other hand, this research concluded that teachers who spoke with students and families in their native language were more effective in improving students.
\end{abstract}

Keywords: inclusive education, inclusion, mainstreaming, teacher qualifications and competencies, support services,

\section{Cited:}

Keser, F., \& Tanrıverdi, A. (2021). Teacher competencies and qualifications for support services in special education institutions. Pamukkale University Journal of Education, 53, 328-354. doi:10.9779.pauefd.848889

\section{Introduction}

\footnotetext{
* This study is based on Firat KESER's thesis number 423992 titled “An Investigation of Support Services for Individuals with Special Needs Regarding Inclusive Practicess"

** Teacher, Ministry of Education, Special Education Practice School, Turkey, https://orcid.org/0000-0002-8578-681X, firatkeser@anadolu.edu.tr

${ }^{* * *}$ Dr., İnünü University, Education Faculty, Special Education Department, Turkey, https://orcid.org/0000-0002-3850$\underline{7419} \underline{\text { arzu.tanriverdi@inonu.edu.tr. }}$
} 
The right to education for persons with special educational needs (SEN) has been improved within the context of Article 26 of the Universal Declaration of Human Rights that states, "Everyone has the right to education." Persons with SEN are described as "a person who differs from their peers in terms of personal qualities and competencies in education" in the Regulations for Special Education Services by the Turkish Ministry of National Education (MoNE, 2018). According to the Merriam Webster Dictionary, persons with SEN are described as "individuals requiring additional or special services or educational adaptations for any and more of a variety of difficulties, such as physical, emotional, behavioral, or learning difficulties or disabilities." The difference between these two descriptions is interpreted as that not every individual with SEN requires special educational support. This difference in definition seems to be affected by the type and level of support services that each country provides to those with SEN. In Turkey, special education services are offered to people with SEN in disaggregated learning environments, co-educational settings, and mainstreaming and inclusive teaching practices. Although mainstreaming and inclusion differ by definition and practice, they are considered as the same terms in Turkey (MoNE, 2020; Armstrong, 2011, p. 18; Booth \& Ainscow, 2002, p. 7; Bryant, Smith \& Bryant, 2016, p. 97; Centre for Studies on Inclusive Education [CSIE], 2011; Keser, 2016; Salend, 2011; Stefano \& Camicia, 2018; Wah, 2010).

Mainstreaming is generally defined as that all individuals with and without special needs receive education together in general education classrooms by making necessary arrangements and adaptations" (Acarlar, 2013; p. 21), and should be taught in the least restrictive environment (Diken \& Batu 2010, p. 6).

Inclusive education is defined as a process of addressing and responding to the diversity of the needs of all students by increasing participation in learning, cultures, and communities and reducing exclusion from education.” (UNESCO, 2009). In inclusive education, regulations for all students of different religions, languages, races, cultures, sexual orientations, socioeconomic levels, geographical locations, and disabilities are made following universal design principles. Differences between mainstreaming and inclusion, which are used as synonymous terms in studies and laws in Turkey, are given below. 
Table 1. Differences between mainstreaming and inclusion (based on Salend, 2011).

\begin{tabular}{|c|c|c|}
\hline Inclusion & & Mainstreaming \\
\hline $\begin{array}{l}\text { - All students have the right to } \\
\text { receive education in general } \\
\text { education classes. }\end{array}$ & Who & $\begin{array}{l}\text { - Selected students can be eligible for a } \\
\text { general education placement only after } \\
\text { their performance assessment. }\end{array}$ \\
\hline $\begin{array}{l}\text { - All students have the right to } \\
\text { access general education } \\
\text { programs and all educational } \\
\text { and social activities. }\end{array}$ & What & $\begin{array}{l}\text { - They have limited access to general } \\
\text { education programs and educational and } \\
\text { social activities. }\end{array}$ \\
\hline $\begin{array}{l}\text { - They are eligible for full-time } \\
\text { placement in general education } \\
\text { classrooms. }\end{array}$ & $\begin{array}{l}\text { Where } \\
\text { or } \\
\text { When }\end{array}$ & $\begin{array}{l}\text { - They are eligible for either full-time or } \\
\text { part-time placement in general } \\
\text { education classrooms. }\end{array}$ \\
\hline $\begin{array}{l}\text { - Focuses on all students' } \\
\text { behavioral, social, academic, } \\
\text { emotional, and physical } \\
\text { development to help them adapt to } \\
\text { society. }\end{array}$ & Why & $\begin{array}{l}\text { - Focuses on students' behavioral, social, } \\
\text { academic, emotional, and physical } \\
\text { development to help them adapt to } \\
\text { society. }\end{array}$ \\
\hline $\begin{array}{l}\text { - Students are provided with } \\
\text { support services in general } \\
\text { education classrooms. } \\
\text { - Special education and general } \\
\text { education support services are } \\
\text { provided together. }\end{array}$ & How & $\begin{array}{l}\text { - Support services are provided in or } \\
\text { outside (support education rooms) of the } \\
\text { general education environment. } \\
\text { - Special education and general education } \\
\text { support services are provided in separate } \\
\text { environments. }\end{array}$ \\
\hline
\end{tabular}

Identifying these two terms clearly in terms of their definitions and differences is very important for the efficiency of support services provided to individuals with SEN. Support services provided to individuals with SEN in Turkey are categorized under two titles: Educational Support Services (ESS) and Social and Economic Support Services (SES). SES aims to support families in their role as caregivers for their children and youth at risk, who cannot meet their basic needs and have hardships in sustaining their daily lives. These services include temporary and continuous economic support, information for individuals with SEN 
and their families, preventive care, support to resolve family problems, information for the choice of profession to people at risk and their families, and guidance on using social resources [The Ministry of Family and Social Policies (MFSP), 2015].

\section{Educational Support Services/Special Education Support Services:}

These services are described as supports for providing students with SEN, their families, teachers, and school personnel with specialist staff, equipment, training, and consultancy. They are offered based on the individualized educational needs of students after their medical and educational assessment and diagnosis. Special education support services (SESS) in Turkey are divided into two categories as inside and outside of school services (The Ministry of National Education [MoNE], 2018; Kış, 2013).

Special education and rehabilitation centers (SERC), where out-of-school special education support services are offered, were handed on to the MoNE in 2007 following Act No. 5378 and gathered under the roof of the MoNE to provide support to schools (Cavkaytar, 2013). In Turkey, some of the responsibilities of private special rehabilitation centers are summarized as the following:

They help students with SEN get prepared for day-to-day life, based on their abilities and interests using special methods, technical equipment, trained staff educational materials. These services also provide special education support that will help students with SEN for adult life in performing their roles in society, improving interpersonal relationships, and working with others collaboratively and in harmony. Moreover, in order to achieve these goals in the fastest possible way, they provide training for families, make certain arrangements, and collaborate with other organizations [schools, counseling and research centers (CRC), nongovernmental organizations (NGOs)] MoNE, 2018; Keser \& Tanrıverdi, 2019; Palas-Karaca, Başgöl, Cangöl, Aslan \& Cangöl, 2016).

In SERC, students with SEN receive 12 hours of training sessions per month, including 8 hours for individuals ( 2 hours a week) and 4 hours of which are for groups ( 1 hour a week). The Ministry of National Education funds these support services (Cavkaytar, 2013); however, families have to pay for the ESS fees (Educational Support Services).

Assigning rooms to provide ESS informal education institutions under the direct affiliation of the MoNE is governed by the provisions of the Circular on Assigning Resource Rooms. The Ministry emphasizes the necessity to provide ESS for students with SEN at all 
levels of all institutions (MoNE, General Directorate of Special Education \& Guidance, 2015). Although the right to education for children with SEN is guaranteed under the relevant laws, they can only have access to ESS, mostly in segregated and uncontrolled environments.

Studies on the quality of ESS offered informal education institutions, special education, and rehabilitation institutions show that teacher qualifications are important. (Karasu \& Mutlu, 2014; Uçar-Remussen \& Kış, 2018). On the other hand, the Ministry of National Education made some updates on the general teacher competencies in 2017 but did not conduct an up-to-date study on teachers' special field qualifications. Special field qualifications of special education itinerant teachers, who offer services to students with SEN, are included in the circular dated 24.07.2008 and numbered B.08.0.0EG.0.13.01.04. These competencies include communication and social skills, curriculum adaptation, ability to cooperate with school, family, and other professional fields, behavior management, and professional improvement. Various studies on the fields of teacher competencies can be found in the literature. The most common challenges faced by teachers in these studies were stated as follows:

Lack of training in educational support services (ESS) during teachers' university education before their graduation; preparing and implementing individualized education program (IEP); identifying and application of teaching methods; dealing with problem behaviors; teaching academic and social skills; limitations in student assessments; difficulty in collaborating with families; providing children with sexual education; creating and using appropriate materials, and communication with CRC and other solution-oriented institutions (Eldeniz-Çetin \& Şen, 2017; Gürgür, Büyükköse \& Kol, 2016; Palas-Karaca et al. 1., 2016; Sivrikaya \& Y1kmis, 2016).

These studies appear to be based on teachers' qualifications in special education, their knowledge, and the challenges they face. However, no studies were found on teachers' qualifications to provide ESS within the scope of inclusion.

\section{The current study}

This research aims to compare the qualifications of teachers who work in special education schools, SERCs and CRCs, in providing ESS to students with SEN. In order to achieve this goal, this study sought to answer the following questions: 
1. What are teacher competencies and qualifications in terms of pedagogical formation education while providing support services?

2. What is the level of teacher competencies and their field qualifications in special education while providing support services?

3. What is the level of teacher competencies in adapting and diversifying while providing support services?

4. What is the level of teacher competencies in student assessment while providing support services?

5. What is the level of teacher competencies in supervising the staff?

6. What is the level of teacher competencies in facilitation inter-institutional coordination?

7. What is the level of teacher competencies about diversities defined in inclusion?

\section{Method}

\section{Research Design}

This research was designed as qualitative research, and focus group interviews were chosen as a data collection technique. Qualitative research is described as a research study that approaches distinctive aspects of social phenomena or situations in their natural environment from an inductive view and is based on understanding participants' emotions, thoughts, and opinions (Ersin \& Bayyurt, 2015; p. 202). This method, which is mainly used in the social sciences, examines issues in depth (Seggie \& Bayyurt, 2015; p. 2). Focus group interviews can be defined as an interview technique designed to get in-depth information for small groups of 6-10 people (Ersin \& Bayyurt, 2015; p. 202).

\section{Participants}

The participants of this study were selected from the teachers working in CRCs, SERCs, special education practice schools, and special education classes in Mardin and Istanbul. Since inclusion practices include diverse languages, religions, and cultures, as previously mentioned, these characteristics were taken into account when selecting the study participants. After interviewing seven focus groups working in seven SERCs in the Mardin province, and two groups working in different schools and CRCs, data saturation was reached, and the data collection process was terminated. One special education practice school and two SERCs in three districts in Istanbul were selected to identify whether they support the data of this study. 
A total of three focus groups and 62 teachers were interviewed in these institutions and schools. The demographic information of the participants is as shown in the table below:

Table 2. Participants by age and sex.

\begin{tabular}{lcc}
\hline Age & Female & Male \\
\hline $20-24$ & 4 & 6 \\
$25-29$ & 14 & 20 \\
$30-35$ & 8 & 8 \\
$40-45$ & 1 & - \\
$50-65$ & - & 1 \\
\hline Total & 27 & 35 \\
\hline
\end{tabular}

Of the participants in this study, 38 were male and 24 female. Ten of the participants were aged between 20-24 years, followed by 25-29 year age group (34), 30-35 year age group (16), 40-45 year age group (1), and 50-65 year age group (1). The majority of the participant teachers are aged between 25-29 years.

Table 3. Participants by graduation field of education.

\begin{tabular}{lcc}
\hline Department & Female & Male \\
\hline Guidance and Psychological Counselling Teaching & - & 2 \\
Special Education Teaching & 4 & 4 \\
Primary School Teaching & 8 & 19 \\
Preschool Teaching & 6 & 2 \\
Child development Expert & 2 & - \\
French Teaching & - & 1 \\
English Teaching & 1 & - \\
Chemistry & - & 1 \\
Psychology & 1 & 2 \\
Sociology & 1 & - \\
& & - \\
Nurse & 1 & 5 \\
Physical Therapy & - & 1 \\
Philosophy & 2 & \\
\hline
\end{tabular}

The distribution of teachers by field of graduation is as follows: Special Education Teacher: 8, Child Development 2, Guidance Psychological Counselling and Teacher: 2, 
Primary School Teacher: 25, Philosophy: 3, Preschool Teacher: 8, English Language Teacher: 1, Psychology: 3, Physiotherapy: 5, Sociology: 1, Biology: 1, Chemistry: 1 and French Teacher: 1. Only 1 out of the eight special education teachers, who were interviewed within the scope of the research, works as an education coordinator in the SERC. The remaining seven special education graduates work in schools under the affiliation of the MoNE, and the majority of teachers working in SERCs are primary school teachers.

Table 4. The participants speak languages

\begin{tabular}{lcc}
\hline Spoken Languages & Female & Male \\
\hline Number of participants who speak Turkish and Kurdish & 12 & 27 \\
Number of participants who speak Turkish and Arabic & 3 & 3 \\
Number of participants who speak English, Turkish and Arabic & 1 & - \\
Number of participants who speak English, Turkish, Kurdish and using & - & 1 \\
sign language & & \\
Number of participants who speak Zazaish and Turkish & 1 & - \\
Number of participants who speak only Turkish & 8 & 1 \\
Number of participants who speak Turkish, Azerbaijani, and English & - & 1 \\
Number of participants who speak Turkish and French & - & 1 \\
Number of participants who speak Turkish, Kurdish, and English & 2 & 1 \\
\hline
\end{tabular}

Demographic data on their spoken languages were collected to determine how teachers communicate with non-Turkish students and provide SES to students. According to the data, eight teachers could speak only Turkish. None of the participant teachers is Syriac or can speak Syriac; however, some teachers can speak English, Kurdish, Sign Language, Zazaish, Arabic, French, and Azerbaijani.

\section{Environment}

Before conducting interviews at SERCs and schools, authorized persons were met, and suitable environments for focus group discussions were specified. The number of teachers and researchers was taken into account while choosing the environment for an ideal interview. It was ensured that participants were in a quiet environment with an air conditioner due to the hot climate of the city where interviews were conducted. Also, audio and visual recording devices were placed in order to transcribe the data more easily.

\section{Data Collection Tools}


Research data were collected with the method of focus group interviews. The researcher then conducted a literature review and created different interview questions for each teacher working in both institutions and schools. Moreover, SERC/Specification Form for Special Education Support Services Provided in Schools (Annex 1), Teacher Personal Information Form (Annex 2), Question Form for Teachers Working in Schools (Annex 3), and Questions Form for Teachers Working in SERCs (Annex 4) was created. Three experts examined the interview forms for their suitability and clearness, and following a pilot interview, the experts re-evaluated and reframed the questions.

\section{Data Collection}

This research collected data from 62 teachers who worked in 1 Special Education Practice School and 9 SERCs in Mardin and Istanbul and attended 12 focus group meetings. Interviews were video/audio recording with video and audio recording devices, and substitute technical equipment was present in the interview rooms for precautionary reasons. Before the interview, the ethics committee approval form for the research (Appendix 6) was presented to the authorized persons and participants, the purpose of the interview was explained, and then teachers signed a voluntary participation form (Appendix 5). The thesis supervisor and researcher conducted the interviews. Two special education teachers also took part in the interviews to keep the field notes.

While collecting the data, some codes were used to analyze the data to protect the confidentiality of the participant teachers and institutions. The data were coded as follows: The number of a sentence followed by the initial of an institution was written in Times New Roman bold font (e.g., S5, Y38, D41). The initial 'I' was added at the beginning of the institution code (e.g., IM96, IA65, ID36). Also, the number of pages in which the interview transcript was written and the city where the interviews were conducted (the letter 'I' for Istanbul and ' $\mathrm{M}$ ' for Mardin) were added to any given finding (e.g., I, FIT [Focus Interview Transcript] p. 19; M. FIT [Focus Interview Transcript] p. 236).

\section{Data Analysis}

A descriptive analysis technique - a technique used in qualitative research methods - was used to analyze the data of this research. A descriptive analysis includes direct quotations to reflect the views of observed interviewees or individuals in an emphatic style. The purpose of this type of analysis is to describe the findings in an organized and interpreted way. In this 
technique, results are obtained through explaining and interpreting descriptions and examining cause and effect relationships. Associating and interpreting the obtained themes and making future inferences may also be among the extents of the researcher's comments (Y1ldırım \& Simsek, 2006).

The field notes kept by four different participant-observers were compared and transcribed in a quiet setting immediately after completing the interviews of this study. The emerging data were verified with the participant observers. In order to prevent data loss, video recordings were watched and transcribed. Once the interview transcripts were completed, the emerging data were read one at a time by the experts and checked for accuracy, while the researcher wrote a research diary simultaneously. All the obtained data were analyzed by developing themes, which were addressed under the section of Findings.

\section{Findings}

The findings of this study were obtained through reanalysis of the data collected for the thesis with the number of 423992 and titled "An Investigation of Support Services for Individuals with Special Needs Regarding Inclusive Practices" and excluded during the thesis process. A literature review conducted for this study shows that no research to date has examined this topic. Therefore, the findings of the research are still up to date.

The themes that come to the fore as a result of the research data analysis are given below. 


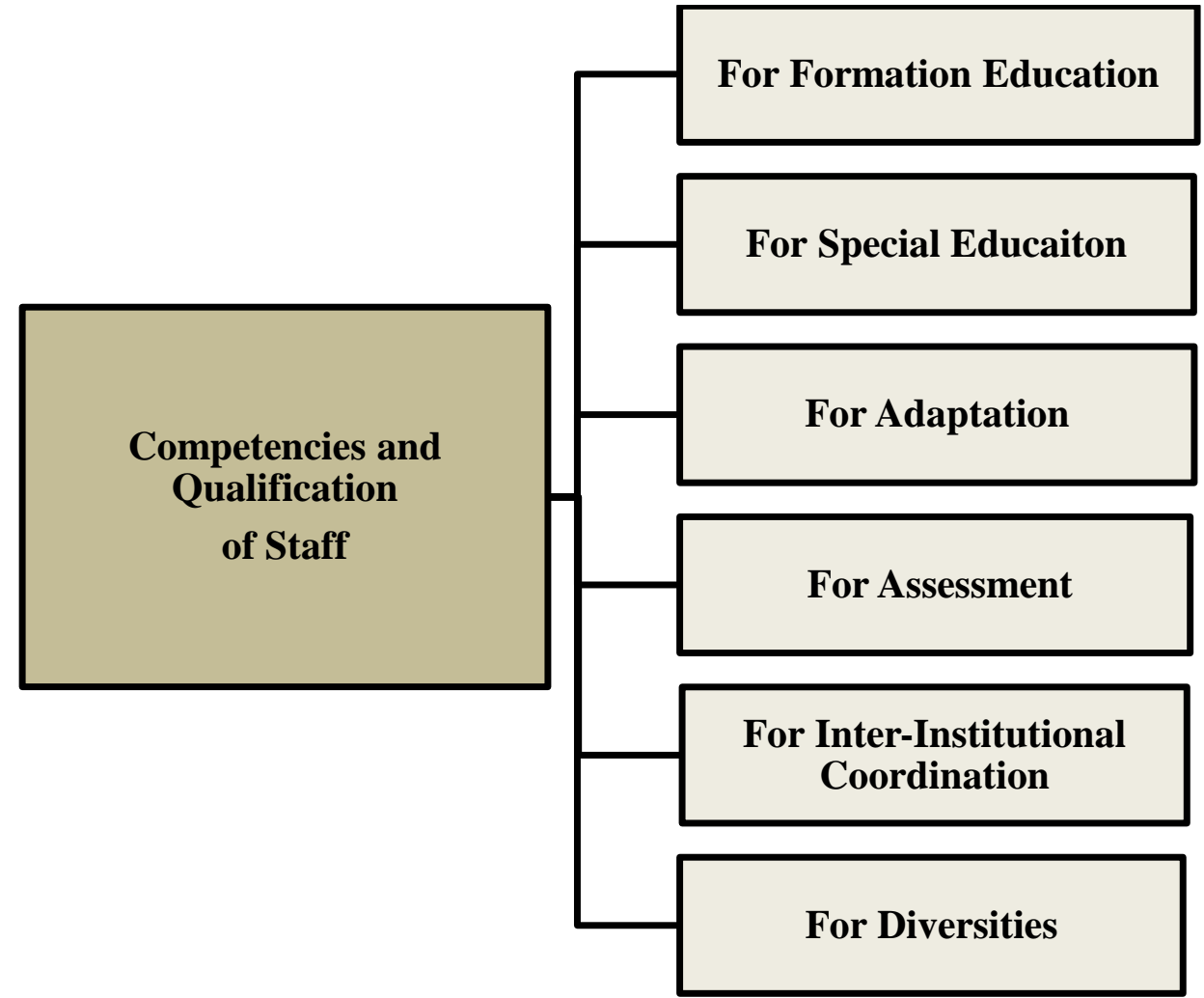

Figure 1. Themes obtained after data analysis

\section{Teacher Qualifications for Pedagogical Formation}

The findings from teachers' pedagogical formation are as follows:

"Group training is given by high school graduates." I15 (m. FIT p. 4) "Education in rehabilitation centers provided to individuals with special needs are seen as if it is a favor." B7 (m. FIT p. 10). "We work here because we have not been appointed to schools." Y2 (m. FIT p. 12). "Children will not listen to their parents, who then ask us to guide their children. However, we cannot have any influences on them as we are not permanent staff.." Y13 (m. FIT p.3).

Based on the findings on teachers' pedagogical formation, teachers working in SERCs do not have sufficient knowledge about pedagogical formation to manage to deal with parents and students, and teachers who have not been appointed to their schools are not appreciated. Teachers working in the institutions coded with ID and IM (i. FIT p. 10-11) also expressed similar statements.

\section{Teachers' Qualifications on Special Education}


The findings obtained regarding the special education qualifications of teachers are as follows:

“. . . We do not have sufficient knowledge on special education to understand mainstreaming student reactions. When a mainstreaming student displays problem behavior in the classroom, we do not know what to do. Therefore, the student disturbs the classroom and eventually becomes an unwanted student." E15 (m FIT p. 25). "I believe that there are many things we need to do for mainstreaming students, but I do not know what to do. I try to get information from the newly appointed teachers, who have taken this course, but I still have difficulties in practice.” E16 (m. FIT p. 25). "In many institutions, only a few teachers have a degree on the field of special education ..." B2 (m FIT p. 10). "We graduated from different fields. Moreover, we work in the field of special education because we have to." H22 (m. FIT p. 12). "Those with a degree in special education criticize us, but we work better than them. Do not be surprised if special education teachers are appointed as classroom teachers in the future.” $\mathbf{H 2 3}$ (m. FIT p. 12). “. . . There is a shortage of qualified personnel in Guidance and Research Centers. The number of teachers with a degree in special education, particularly in these centers, is very limited. Furthermore, this adversely affects us ." IM74 (i. FIT p. 9). "Although I have a degree in special education, I feel inadequate." IM76 (i. FIT p. 10).

Teachers working in the institutions coded as ' $\mathbf{B}$ ' and ' $\mathbf{S}$ ' (m. FIT p. 10, 13) also expressed similar statements.

The findings of teacher qualifications in special education indicate that teachers are insufficient in dealing with mainstreaming students; even the teachers with a degree in special education feel inadequate in practicing their profession. The majority of teachers working in SERCs consist of teachers, who have graduated from other departments than special education, and are unassigned teachers. Consequently, the research found that these teachers are insufficient in dealing with students with special needs. Furthermore, the teachers working in Guidance and Research Centers carry out incorrect assessments due to insufficient knowledge on special education.

\section{Teacher Qualifications for Planning IEP and Parent Training}

The findings regarding teachers' qualifications about planning are as follows: 
“... Their goals are making efforts to make parents happy rather than being beneficial for students. I know that the child's muscles are weak, and I work accordingly, but the parents want me to teach him how to read and write. What has cared most is acting as wealthy parents wish." IM69 (i. FIT p. 9).

The teachers coded as H, C (m. FIT p. 13,16), IA, IM (i. FIT p. 16, 9) expressed similar statements.

The findings on teachers' planning skills show that teachers providing general education do not attach importance to Individual Education Programs for individuals with special needs. Teachers working in SERCs ground on Individual Education Programs sent by CRC instead of preparing them themselves. However, the teachers in some SERCs seem to perform their teaching based on parents' requests rather than achieving the goals of the student's Individual Education Program.

\section{Teacher Competencies in Teaching Methods and Techniques, Problem Behaviour Therapy,} and Ability to Cope with Adolescent Problems

The participant teachers' views about the teaching methods and techniques that they use in their teaching, problem behavior treatment, and adolescent problems are as follows:

“...We see that majority of teachers have the knowledge of these methods, but cannot effectively implement them. We see that the "voice" as violence does not remain in us." IM37 (i. FIT p. 5). “There is no adaptation for diverse sexual orientation for adolescents. ”Y15 (i. FIT p. 22). “ . . and in time, we find ourselves performing the practices only requested by parents rather than the right things we know. We are purposely doing what is useless for the child. $\mathbf{H 2 9}$ (m. FIT p. 13)“. . . Sometimes we cannot read the reactions of mainstreaming students. We cannot do anything when they display a problematic behavior.” E15 (m. FIT p. 4). “Also, some male students do not recognize female teachers' authority. They reject my authority. They only take notice of me if I say something like, "I will go and get Mr. Levent [ a male teacher].” $\mathbf{H 3 5}$ (m. FIT p. 22). “...We realized that the methods and techniques taught to us at school would not work at some point when we started teaching and implementing them." IM36 (i. FIT p. 5) 
The teachers coded IM33 (i. FIT p. 4, 8, and 9), H and K (m. FIT p. 4, 18) expressed similar statements.

A brief overview of the findings shows that the teachers do not know diverse teaching methods and strategies, and those who know cannot implement them. They only use the methods and techniques requested by parents rather than those that will be effective and useful for the students by the IEP. The findings also show that the students displaying problem behaviors tend to be in male teachers' classrooms, and the teachers appear to be inadequate to provide sexual education and deal with LGBT students. Furthermore, although teachers with a degree in special education know diverse teaching methods and strategies, they seem to have difficulty implementing them in the classroom.

\section{Teachers Competencies for Providing Parent Training and Communicational Skills with} Families

The findings obtained on teachers' communicational skills with families of individuals with special needs and parent training are as follows:

". . . Since family education programs are scheduled to after 5 PM, they cannot be conducted." I11 (m. FIT p. 4).

Teachers coded with $\mathbf{S}, \mathbf{U}, \mathbf{H}$, and $\mathbf{C}$ working in SERCs also expressed similar statements.

"We can only communicate with families if we can speak their mother tongue. However, if the teacher cannot speak families' mother tongue, then they cannot communicate.” IM58 (i. FIT p. 7). “I cannot speak Kurdish. I am struggling with communicating with the student and parents. I get reactions from the parents since I cannot speak Kurdish.” H42 (m. FIT p. 22).

The teachers working at the institutions coded as K, C, D (m. FIT p. 12, 22, 33.), and C (m. FIT p. 33) also expressed similar expressions.

Overall, the present study indicates that parent training programs are not provided to the families, and the current training programs are only limited to teachers. It is also suggested that teachers can speak families' mother tongue, facilitates communication with families, and increases teachers' acceptability, while parents disregard the teachers who cannot speak their mother tongue. 


\section{Competencies of Inspectors for Special Education Field Knowledge}

The findings obtained on the field knowledge of inspectors in special education are as follows:

\footnotetext{
"Inspection of special education institutions is perfunctory, and all they do is document checking. Inspections should be performed for longer durations, but they do not, as the educational background of inspectors is inadequate.”S22 (m. FIT p. 13). “Inspectors should have a better knowledge of special education.” C33 (m. FIT p. 10).
}

The teachers working in the coded institutions as $\mathbf{Y}, \mathbf{B}, \mathbf{K},(\mathrm{m}$. FIT p. 18, 29, 36) and ID (i. FIT p. 11) also made similar statements.

These findings show that CRCs, SERCs, and schools are either not inspected or perfunctorily inspected for only document checking, and this seems to allow teachers to neglect their duties during their working hours, causing discord among teachers in terms of working methods. These findings also include the fact that inspectors have inadequate knowledge in the field of special education.

\section{Teachers' Competency for Technology Adaptation}

The findings obtained on teachers' technology adaptation are as follows;

“. . I I use the child's experiences rather than using materials. We do not have the chance to use technology.” H11 (m. FIT p. 4). “. . We do not use alternative technology." $\mathbf{H 4}$ (m. FIT p. 7). "It would be better if we used DVD and computer. Technology that we can use is limited." ID3 (i. FIT p. 11). "We had a smart board in the previous school I worked, and I benefitted a lot from it. However, we did not have a computer program for special education and adapted the program created for primary school education to special education. We do not have it here in this school and have to deal with the students individually using papers. Thus, it is hard to draw students' attention now." IM6 (i. FIT p. 1).

Teachers working in the institutions coded as IM7, IA1, IA16 (i. FIT p. 1, 15,16), and C61 (m. FIT p. 33) also support the findings. 
The findings of this study reveal that teachers' level of using technology varies. The teachers, who work in SERCs, use very little technology, and those, who work at schools, do not have the competency for technology adaptation for students with special needs. Teachers' struggle to use technology in the classroom appears to be caused by the lack of or very limited technological supports.

\section{Teachers' Competencies in Formal and Informal Assessment}

Teachers' views on their competencies in the formal and informal assessment are given below:

"Although we do not have students with intellectual disabilities, they have been misdiagnosed due to their language disorders. Moreover, this leads them to display problem behaviors. K16 (m. FIT p. 3). “ . . . CRCs [Counselling and Research Centers] conduct an assessment in just a few minutes without considering children's diverse cultures and languages. ID25 (i FIT p. 13). "We have a problem with an accurate diagnosis. For instance, the child's report states that he has a physical disability without a proper assessment. Although the child needs physical therapy, he cannot receive any as it is not written in his report-H9 (m FIT p. 1). "The goals are not set for the modules by the child's disability... "' K15 (m. FIT p. 2). "CRCs are always setting the same goals for all children." C36 (m. FIT p. 1). “. . . Some parents do not want CRCs to make a report for their children so that they are not labeled with a disability... " E7 (m. FIT p. 20).

Based on the findings obtained from student assessments, the problem appears to be caused by the lack of staff qualifications in CRCs. These findings suggest that the goals set for children do not match their disabilities and academic levels, are used for all children regardless of their characteristics, and therefore, students begin to display problem behaviors. Furthermore, it is suggested that staff in CRCs conduct assessments without adapting them to the needs of children with no informal or language and culture-based evaluation processes, which causes labeling of children.

\section{Teacher Competencies for Inter-Institutional Coordination}

The findings of the communication among the staff working in schools, CRCs, and SERCs are as follows: 
“. . . Last year we went to a school visit, and they did not even let us in. They do not consider us as teachers and be bothered with communicating with us. They look at the situation with a civil servant mentality; all they want seems to be finishing the working hours and going back home." IA14 (i. FIT p. 16). “We do not even get in contact with rehabilitation centers for support services. Words fail us as they do not provide correct methods of teaching with the students; they have them write words like 'mother, father' when they do not even know how to hold a pencil properly. . ." IM68 (i. FIT p. 9). “. . . School directors seem to prevent teachers from communicating with rehabilitation centers." ID22 (i. FIT p. 13)

Similar findings were found in the institutions coded as $\mathbf{S}, \mathbf{Y}, \mathbf{K}$ (m. FIT p. 7, 13, 36) and ID, IA (i. FIT p. 13, 17).

The overall findings of this study reveal that staff does not communicate among each other and exchange information for students with special needs. Also, teachers working in special education schools and classes appear not to see the teachers working SERCs as equals to themselves as they position themselves as an authority in special education.

\section{Staff Competencies for Dealing with Diversity of Language, Religion, Culture and Sexual Orientation}

The findings of the most common issues emphasized by the teachers who participated in this research on diverse languages, religions, and sexual orientation are as the following:

"Language barriers are leading to misdiagnosis. When a child's mother tongue is different, then he/she is diagnosed differently." $\mathbf{C 3 9}$ (m. FIT p. 21). "If children do not understand the instructions given in Turkish, then we will have to give them in Kurdish.” $\mathbf{K 8}$ (m. FIT p. 35). "Language barriers also go for inspections. When an inspector cannot speak Kurdish, he/she thinks that the child knows nothing; we communicate with the children in Turkish during inspections. Moreover, therefore, the child gives us a blank look.” K10 (m. FIT p. 36). “Last year, I could not communicate with the mother of one of my students, as she could not speak Turkish. The father spoke Turkish, and although we asked him to come to the school, he did not. Furthermore, we lost the child, and the family took him from school 
because we could not communicate with his mother. IM62 (i FIT p. 6). “. .

. When families go to CRCs, they cannot explain their Turkish problems, and teachers working in CRCs cannot speak families' mother tongue.

Moreover, this leads to misdiagnosis of children.” C39 (m. FIT p. 21).

"When children, who cannot speak Turkish, come to our institution, we refer them to the teachers speaking Kurdish, and they can communicate with them in Kurdish. However, we then begin using Turkish to communicate with them so that they gain social acceptance since the majority of society speaks Turkish." ID10 (i. FIT p. 11).

These findings reveal that the staff who does not speak children's mother tongue have difficulty communicating with them, and their family goes wrong with performance appraisals due to the language barrier, which leads to various problems. However, teachers speaking children's mother tongue seem to establish communication with children and families more easily, making a greater contribution to children's academic improvement. Similar findings were obtained from the institutions coded as IM, ID (i. FIT p. 6, 12), and E (m. FIT p. 39).

Teachers' statements about diverse cultures and religions are as follows:

"We did not take any courses addressing diversity at university except a course named 'Individual Diversities.'” IM59 (i FIT p. 8) “We do not have any individual adaptation plans for diverse religious sects..” ID18 (i FIT p.12). “. . . We can suggest that some regulations should be made on the diversity of culture, language and religion as we encounter some problems in this regard” $\mathbf{B 2 0}$ (m. FIT p. 42).

Furthermore, the teachers appear to make little or no adaptations for diverse religions, cultures, and sexual orientations. Moreover, the findings show that this is caused by the fact that parents make no demand to adapt their children's diverse backgrounds to the dominant religion and culture rather than teacher incompetence.

\section{Discussion}

With the right to education becoming increasingly important, global education systems have been forced to update some regulations and make amendments to existing support services provided to individuals with disadvantaged and special needs within the scope of inclusive education based on the philosophy of "education for all." Teacher competencies are crucial in 
order to successfully provide these support services to individuals with special education needs. This research, which deals with teacher qualifications and competencies within the scope of support services, used a qualitative research method, and the findings of the research were obtained through focus group interviews.

This research revealed the following findings: Many private educational institutions, especially SERCs, employ out-of-field teachers, and these teachers have insufficient pedagogical formation to teach students academic skills and provide parent training. They have limited knowledge of special education required for teaching concepts and skills to students with special needs, particularly mainstreaming students (and the same issues apply to inspectors in special educational institutions). Teachers do not have the competencies and qualifications to plan IEPs and assess students formally and informally. Teachers' knowledge of teaching methodology is insufficient and up to date to cope with students' problem behaviors, teach their students concepts and skills, and provide parent training and sexual education. Additionally, teachers working in CRCs do not have the qualifications to test and assess students based on their performances.

Furthermore, they lack the competencies and qualifications to diversify and adapt to students of different languages, religions, cultures, and sexual orientations. Therefore, they appear to have difficulty establishing effective communication with their students and families and do not have a high opinion of parents. Moreover, finally, the research finds that teachers struggle in technology adaptation and communicating with the staff to provide the necessary assistance in offering support services to students. It is seen that the findings obtained in this study are in parallel with the literature. For example, in the study conducted by UçarRasmussen \& Kış (2018), it was stated that teachers who graduated from different branches but worked in the field of special education do not have the necessary equipment for planning, evaluation, family education, and student cooperation.

It was found that the teachers working in the field of special education had limitations in basic special education (Yıkmış \& Özbey, 2009), and training (Altınkurt, 2008; Karasu \& Mutlu, 2014) and experienced problems. It was stated that these problems and insufficient knowledge of teachers lead to problems affecting the developmental areas of students and some negativities in classroom management (Weiss, Markowetz, \& Kiel, 2018). Furthermore, the research findings demonstrate that teachers must have special education methods and technics, planning suitable IEP for students and evaluating the IEP's is difficult for them, and the IEP's prepared by staff working in CRC's do not match with students' level. These findings also coincide with the literature (Al-Shammari \& Hornby 2020; Avc1oğlu, 2012). 
Along with the above, teachers working in ÖERMs have difficulty in providing applied family training, are not qualified in-house, and inter-institutional communication (Tiryakioğlu, 2009; Korucu, 2005), and do not have enough proficiency in providing sexual education and therefore It was stated that they should receive in-service training on this subject (Palas-Karaca et al. 1. 2016). On the other hand, it has been stated that it is important that the personnel working in ÖERMs have the necessary equipment for special education (Sağırlığlu, 2006). It is stated that the findings obtained about auditing are parallel to the literature; It was stated that the knowledge of special education inspectors was insufficient, inspections were mostly carried out in the form of document checks, but special education inspectors should be experts in special education methods and techniques, unlike general education inspectors (Zigmond, 2003).

It is seen that the findings on adaptation also coincide with the literature. It is difficult for teachers to provide education and support services for the differences (language, ethnicity, belief, socioeconomic level, etc.) based on the philosophy of education for everyone and included in the integration practices; For this reason, it is mentioned that it is important for teachers to develop teaching strategies for differences, to provide appropriate technology and to cooperate with neighboring schools on these issues (Nel, Tlale, Engelbrecht \& Nel, 2016). In this research, one of the findings that come to the forefront the most is that individuals with special needs have problems because of their mother tongue. It has been stated that when evaluations are done in a different language than students' native language, it leads to the wrong diagnosis. Even though children have no limitations in any field, it was found difficult to communicate with the kids whose mother tongue is different from the official language and also if communication was established with the children in their mother tongue, kids showed faster improvements (Baker, 2011; Karasu \& Mutlu, 2014; Rodríguez, 2015; Villages, 2019). Besides that, it was reached that if communication and organization in parent education with families of individuals with special needs in their mother tongue, students' academic success and participation of the families increased (Onorato, 2016; Jegatheesan, Miller \& Fowler, 2010).

\section{Conclusions}

The following conclusions were drawn from this study: Teachers who participated in this research and work in SERCs, CRCs, special education practice schools, and special education classes, there are only very few teachers with a degree in special education (12.9\%). The percentage of special education teachers who work in SERCs is $1.6 \%$. The teachers (including 
special education teachers) typically struggle to teach the students skills and concepts, deal with problem behaviors, provide sexual education and parent training, communicate in families' mother tongue, plan IEPs, assess students formally and informally, and use technology for IEP. Also, teachers struggle to provide support services for students with diverse language, religion, culture, and sexual orientation, while the teachers speaking child and family's mother tongue make a greater contribution to the improvement of students.

This study recommends that the Regulations for Special Education Services should primarily be updated to bring teachers to a sufficient level to provide special education support services within the scope of inclusion practices. It is suggested that the concepts of mainstreaming and inclusion, described under the same title in the Turkish regulations but separately in the world literature, should be described as two different concepts, and the support services within the scope of inclusion should clearly be defined. It is also recommended that the content of employee training for these support services should be updated within the relevant laws. Additionally, scientific-based comprehensive intervention programs can be included in in-service training to enhance teacher competencies in planning, assessment, parent training, sexual education, classroom management, teaching concepts and skills, social and communication skills, and expressive language skills.

On the other hand, children with special needs and disadvantaged children whose mother tongue are different had difficulty in the first periods when they started school due to the only official language of Turkish (Karasu \& Mutlu, 2014); in order to minimize these difficulties, it is seen that bilingual special education practices have been implemented in practice (Gampe, Wermelinger \& Daum, 2019; Bergroth \& Palviainen 2017; García \& Lin, 2017). It has been suggested that legal regulation must be made to provide support services about different languages, religions, cultures, and sexual orientation and inclusive education applications for the realization of bilingual special education practices that are handled based on a mother tongue or mostly transitional model. It is also recommended that the course of individual diversities provided within the Special Education Teacher Training programs at universities should include courses, such as human rights, diversity of languages, religions, cultures, and sexual orientation. A future study could suggest that the concepts of mainstreaming and inclusion should be addressed separately, and teaching practices carried out both in students' mother tongues, and official language should be examined comparatively. 
However, these results were based upon data from the views and data of the teachers working in the cities of Mardin and Istanbul. It was the month of Ramadan during which the research data were collected, so teachers who fasted also had to be included in focus group meetings along with those who did not fast, which could be regarded as another limitedness of this research.

Ethical Approval: This research was conducted with the permission of the Abant İzzet Baysal University Human Studies in Social Sciences ethics committee with the decision no 2014/60 dated 20.06.2014

Conflict Interest: The authors reported no potential conflict of interest.

Authors Contributions: Both authors contributed equally to idea and design, data collection and analysis, and interpretation of the article's findings. 


\section{References}

Acarlar, F. (2013). Kaynaştırma modeli ve özel gereksinimli çocukların özellikleri. Okul Öncesinde Kaynaştırma, 21-74.

Al-Shammari, Z., \& Hornby, G. (2020). Special education teachers' knowledge and experience of IEPs in the education of students with special educational needs. International Journal of Disability, Development, and Education, 67(2), 167 181.

Altınkurt, N. (2008). Özel eğitim ve rehabilitasyon merkezlerinde yaşanilan sorunlar ve çözüm önerileri. Unpublished master dissertation. Dokuz Eylül Üniversitesi Eğitim Bilimleri Enstitüsü, İzmir.

Armstrong, F. (2011). School cultures, teaching, and learning. (Ed. G. Richards \& F. Armstrong). Teaching and learning in diverse and inclusive classrooms içinde (s. 118). Newyork: Routledge.

ASB [MFSP], (2015) Sosyal ve ekonomik destek hizmetleri hakkında yönetmelik. Recrived from www.resmigazete.gov.tr/eskiler/2015/03/20150303-3.htm/ on 12 September 2020 .

Avcıoğlu, H. (2012). Rehberlik ve araştırma merkez (RAM) müdürlerinin tanılama, yerleştirme-izleme, bireyselleştirilmiş eğitim programı (BEP) geliştirme ve kaynaştırma uygulamasında karşılaşılan sorunlara ilişkin algıları. Kuram ve Uygulamada Eğitim Bilimleri, 12(3), 2009-2031.

Baker, C. (2011). Foundations of bilingual education and bilingualism. Multilingual matters: 2nd EditionBergroth, M., \& Palviainen, Å. (2017). Bilingual children as policy agents: Language policy and education policy in minority language medium Early Childhood Education and Care. Multilingual, 36(4), 375-399.

Booth, T..\& Ainscow, M. (2002). Index for Inclusion: Developing Learning and Participation in Schools. Bristol: Centre for Studies on Inclusive Education. Retrieved from www.csie.org.uk/publications/inclusion-index-explained.shtml. on 18 June 2020. 
Bryant, D., Smith, D., \& Bryant, B. (2008). Teaching students with special needs: In inclusive classrooms. Boston, MA: Pearsons Education, Inc

Cavkaytar, A. (2013). Özel eğitime gereksinim duyan çocuklar ve özel eğitim. (Ed. İ.H. Diken). Özel eğitime gereksinimi olan ögrenciler ve özel eğitim içinde. Ankara: Pegem Yayıncilik.

CSIE, (2011). 'What is inclusion? Retrieved from http:// www.csie.org.uk/inclusion/what. shtml. on 19 April 2020.

Diken, İ. H. \& Batu, S. (2010). Kaynaştırmaya giriş. (Editörler İ. H. Diken \& S. Batu) İlköğretimde kaynaştırma, içinde (s. 2-23.)

Eldeniz-Çetin, M. \& Şen, S. G., (2017) Özel eğitim ve rehabilitasyon merkezlerinde çalışan öğretmenlerin sorunlarının belirlenmesi. International Journal of Social Science. Number: 59 , p. 53-69 Doi number:http://dx.doi.org/10.9761/JASSS7133

Ersin P. \& Bayyurt, Y. (Eds). (2015). Odak Grup Görüşmeleri. (Editörler F. N. Seggie \& Y. Bayyurt) Nitel araştırma: Yöntem, teknik, analiz ve yaklaşımları içinde (s.202-218) Ankara: Anı Yayınc1lık.

Gampe, A., Wermelinger, S., \& Daum, M. M. (2019). Bilingual children adapt to the needs of their communication partners, and monolinguals do not. Child Development, 90(1), 98-107.

García, O., \& Lin, A. (2017). Extending understandings of bilingual and multilingual education. (Eds O. García A. M. Y. Lin \& S. May) Bilingual and multilingual education, 1-20. 3. Bask1. Springer.

Gürgür, H., Büyükköse, D., \& Kol, Ç. (2016). Özel eğitim ve rehabilitasyon merkezlerinde işitme kayıplı öğrencilere sunulan destek hizmetler: öğretmen görüşleri. Elementary Education Online, 15(4).

Jegatheesan, B., Miller, P. J., \& Fowler, S. A. (2010). Autism from a religious perspective: A study of parental beliefs in South Asian Muslim immigrant families. Focus on Autism and Other Developmental Disabilities, 25(2), 98-109. 
Karasu, T., \& Mutlu, Y. (2014). Öğretmenlerin perspektifinden özel eğitimde yaşanan sorunlar ve çözüm önerileri: Muş il örneği. Anemon Muş Alparslan Üniversitesi Sosyal Bilimler Dergisi, 2(1), 47-66.

Keser, F. (2016). Destek Hizmetlerin Bütünleştirme Uygulamaları Açısından Incelenmesi. Düsseldorf: Lambert: Almanya.

Keser, F. \& Tanriverdi, A. (2019). Determining support services received by individuals with special needs living in Mardin and Istanbul. The Journal of International Social Research, S. 12(62), 1058-1066

Kış, H. (2013). Destek ĕgitim odalarındaki uygulamalara ilişkin rehber ögretmenler ve özel ĕgitim sınıf öğretmenlerinin görüşleri. Unpublished master dissertation Abant İzzet Baysal Üniversitesi Eğitim Bilimler Enstitüsü, Bolu.

Korucu, N. (2005). Türkiye'de Özel Eğitim ve Rehabilitasyon Hizmeti Veren Kuruluşların Karşılaştı̆̆ı Güçlüklerin Analizi: Kuruluş Sahipleri, Müdür, Öğretmen ve Aileler Açısından. Unpublished master dissertation. Selçuk Üniversitesi, Sosyal Bilimler Enstitüsü, Konya.

MEB [MoNE] (2020). Özel Ĕ̌itim Hakkında Kanun Hükmünde Kararname ve Özel Ĕ̈itim HizmetleriYönetmeliği. Retrieved from https://orgm.meb.gov.tr/meb_iys_dosyalar /2020_06/24163215_ozel_eYitim_yonetmeliYi_son_hali.pdf on 25 March 2020.

MEB [MoNE] (2018). Özel Eğitim Hakkında Kanun Hükmünde Kararname ve Özel Ĕgitim HizmetleriYönetmeliği. Retrieved from http://www.resmigazete.gov.tr/eskiler/20180 /20180707-8.htm. on 24 April 2020.

MEB[MoNE], (2008). Milli Ĕgitim Bakanlı̆̆l Öğretmen Yetiştirme ve Ĕgitimi Genel Müdürlüğ̈̈8.03.2008 tarihli B.08.0.0EG.0.13.01.04-/1835 sayılı genelgesi. Retrieved from otmg.meb.gov.tr/belgeler/alanyeterlikler/ozelalan\%20yeterlikleri.pdf 14 September 2020.

Nel, N. M., Tlale, L. D. N., Engelbrecht, P., \& Nel, M. (2016). Teachers' perceptions of education support structures in the implementation of inclusive education in South Africa. Koers, ISNN2304-8557 81(3),1-14. Retrieved from http://dx.doi.org/10.19108/koers.81.3.22 49. on 15 December 2020. 
F.Keser \& A. Tanriverdi / Pamukkale University Journal of Education, 53, 328-354, 2021

Onorato, P. G. (2016). Investigating the Effects of a Parent-Mediated Intervention on Latino Parent-Child Verbal Interaction and Children's Receptive Vocabulary. Unpublished doctoral dissertation. Virginia Commonwealth University, Richmond.

Palas-Karaca, P., Başgöl, Ş., Cangöl, E., Aslan, E., \& Cangöl, S. (2016). Özel eğitim ve rehabilitasyon merkezi çalışanlarının engelli bireylerin cinsel eğitimi konusundaki görüşleri. Balıkesir Sağlık Bilimleri Dergisi, 5(1), 13-17.

Rasmussen, M. U., \& Kış, A. (2018). Qualifications of subject teachers in special education schools. Journal of Education and Training Studies, 6(4), 48-57.

Rodríguez, D. (2015). Bilingual special education: Investigating and implementing evidencebased practices in schools. Journal of Multilingual Education Research, 6(1), 2.

Salend, J. Spencer (2011). Creating inclusive classrooms: Effective and reflective practices 7. New Jersey: Pearson.

Sağıroğlu, N. (2006). Özel gereksinimli bireylere sahip ailelerin çocuklarının devam ettiği özel eğitim ve rehabilitasyon merkezlerinden beklentileri. Unpublished master dissertation. Abant İzzet Baysal Üniversitesi, Sosyal Bilimler Enstitüsü, Bolu.

Sarı, H., Atbaşı, Z., \& Çitil, M. (2017). Özel eğitim ve rehabilitasyon merkezlerinde görev yapan öğretmenlerin aile eğitimi konusundaki yeterliliklerinin belirlenmesi. Kırşehir Ĕ̈itim Fakültesi Dergisi, 18(3), 668-684.

Sivrikaya, T., \& Yıkmış, A. (2016). Özel eğitim sınıflarında görev yapan özel eğitim mezunu olan ve olmayan öğretmenlerin öğretim süreciyle ilgili gereksinimleri. Abant İzet Baysal Üniversitesi Eğitim Fakültesi Dergisi, 16(4), 1984-2001.

Seggie, F. N. \& Bayyurt, Y., (Eds). (2015). Nitel araştirma yöntem, teknik, analiz ve yaklaşimlari. Ankara: Anı Yayıncılık.

Stefano, M., \& Camicia S. P. (2018). Transnational Civic Education and Emergent Bilinguals in a Dual Language Setting. Educational Science, 8(3), 1-22.

Tiryakioğlu, Ö. (2009). Rehberlik ve araştirma merkezi müdürlerinin özel ĕ̌itim bölümünün sorunlarini algilamalari, Unpublished master dissertation. Abant İzzet Baysal Üniversitesi, Bolu 
United Nations Educational, Scientific and Cultural Organization. (2009). Defining an inclusive education agenda: Reflections around the 48th session of the international conference on education. Geneva: UNESCO International Bureau of Education

UNESCO. (2009). Policy Guidelines on Inclusion in Education. Paris.

Villegas, M. (2019). Determining differences in bilingualism and learning disabilities. Community Engagement Student Work.

Yıkmış, A., \& Ozbey, F. Y. (2009). Otistik çocuğa sahip annelerin çocuklarinin devam ettiği rehabilitasyon merkezlerinden beklentilerinin ve önerilerinin belirlenmesi. International Online Journal of Educational Sciences, 1(1), 124-153.

Zigmond, N. (2003). Where Should Students with Disabilities Receive Special Education Sevices? Is one Place Better Than Another? The Journal of Special Education. 37 (3). 193-199.

Wah, L.L. (2010). Different strategies for embracing inclusıve education: a snapshot of individual cases from three countries. International journal of special education, 3, 98-109.

Weiss, S., Markowetz, R., \& Kiel, E. (2018). How to teach students with moderate and severe intellectual disabilities in inclusive and special education settings: Teachers' perspectives on skills, knowledge, and attitudes. European Educational Research Journal, 17(6), 837-856. 


\title{
Özel Eğitim Kurumlarındaki Öğretmenlerin Destek Hizmetlerini Sunma Yeterlilikleri*
}

\author{
Firat KESER $^{* *} \quad$ Arzu TANRIVERDI ${ }^{* * *}$
}

• Gelis Tarihi: 30.12.2020 • Kabul Tarihi: 23.04.2021 • Çevrimiçi Yayın Tarihi: 23.04.2021

\section{$\ddot{\mathbf{O} z}$}

$\mathrm{Bu}$ araştırmanın amacı, özel gereksinimli bireylere (ÖGB) destek eğitim hizmetleri (DEH) sağlamak için özel eğitim okullarında, özel eğitim sınıflarında, rehberlik araştırma merkezleri (RAM) ve özel eğitim rehabilitasyon merkezlerinde (ÖERM) çalışan öğretmenlerin yeterliklerini tartışmaktır. $\mathrm{Bu}$ araştırma nitel bir araştırma olarak tasarlanmış ve veri toplama tekniği olarak odak grup görüşmeleri seçilmiştir. Araştırmaya RAM, ÖERM, özel eğitim okulları ve sınıflarda çalışan 62 öğretmen katılmıştır. Araştırma verilerini analiz etmek için nitel araştırma yöntemlerinde kullanılan betimsel analiz yöntemi kullanılmıştır. Araştırmanın bulguları 6 farklı tema altında incelenmiştir. Öğretmenlerin (özel eğitim öğretmenleri dahil) beceri ve kavramları öğretme, problem davranışların sağaltımında, öğrencilerle cinsel eğitim ve veli eğitimi vermede, ailelerle anadillerinde iletişim kurmada, öğrencinin bireysel eğitim programı (BEP) planlamada, öğrencileri formel ve informel olarak değerlendirmede, teknolojiyi öğrencilerin BEP'lerindeki amaçlara uyarlamada zorlandıkları görülmüştür. Bununla birlikte bütünleştirilmiş bir eğitim sisteminde, öğretmenlerin farklı dil, din, kültür ve cinsel yönelime sahip bireylere destek hizmetleri sunmadıkları/sunamadıkları görülmüştür. Öte yandan bu araştırmada, öğrenci ve aileleri ile ana dillerinde konuşan öğretmenlerin öğrencilerin gelişiminde daha etkili olduğu sonucuna varılmıştır.

Anahtar sözcükler: bütünleştirilmiş eğitim, bütünleştirme, kaynaştırma, öğretmen yeterlilikleri, destek hizmetler

Atıf:

Keser, F. ve Tanrıverdi, A. (2021). Özel eğitim kurumlarındaki öğretmenlerin destek hizmetlerini sunma yeterlilikleri. Pamukkale Üniversitesi Eğitim Fakültesi Dergisi, 53, 328354.doi:10.9779.pauefd.848889

\footnotetext{
* Bu araştırma Fırat KESER'in 423992 numaralı “Özel Gereksinimli Bireylerin Aldıkları Destek Hizmetlerin Bütünleştirme Uygulamaları Açısından İncelenmesi” tezinin bulgularına dayanmaktadır

** Öğretmen Milli Eğitim Bakanlığı, Özel Eğitim Uygulama Okulu, Türkiye, https://orcid.org/0000-0002-8578-681X, firatkeser@anadolu.edu.tr

*** Dr., İnünü Üniversitesi, Eğirim Fakultesi, Özel Eğitim Bölümü Türkiye, https://orcid.org/0000-0002-3850-7419 arzu.tanriverdi@inonu.edu.tr.
} 


\section{Giriş}

İnsan Hakları Evrensel Beyannamesinin 26. maddesinde yer alan "Herkes eğitim hakkına sahiptir" ilkesi bağlamında özel gereksinimli bireylerin eğitim haklarında iyileştirmeler yapılmıştır. Özel gereksinimli birey (ÖGB), Özel Eğitim Hizmetleri Yönetmeliğinde "Bireysel özellikleri ve eğitim yeterlilikleri açısından akranlarından anlamlı farklılık gösteren birey" olarak tanımlanmaktadır (MEB, 2018). Merriam Webster Sözlüğüne göre özel gereksinimli birey: fiziksel, duygusal, davranışsal veya öğrenme güçlüğü ya da yetersizliği gibi çeşitli zorluklardan herhangi biri ve/veya birden fazlası için ek veya özel hizmetler veya eğitimsel uyarlamalar gerektiren birey olarak tanımlanmaktadır (https://www.merriamwebster.com/dictionary/specialneeds, 2020). Bu iki tanım arasındaki fark, her ÖGB'in özel eğitim desteğine gereksinimi olmadığı şeklinde anlaşılmaktadır. Bu tanım farkının, ülkelerin ÖGB'lere sağlanan destek hizmetlerin (DH) tür ve düzeyinin ülkelerin bu konudaki politikalarından etkilendiği görülmektedir. Türkiye'de ÖGB'lere sunulan özel eğitim hizmetleri ayrıştırılmış ortamlarda (özel eğitim okullarında) ve birlikte eğitim ortamlarında (genel eğitim okullarında) kaynaştırma ve bütünleştirme uygulamaları olarak sunulmaktadır. Kaynaştırma ve bütünleştirmenin tanımı ve uygulaması birbirinden (MEB, 2020; Armstrong, 2011, s. 18; Booth ve Ainscow, 2002, s. 7; Stefano ve Camicia, 2018, Bryant, Smith ve Bryant, 2016, s. 97; Keser, 2016, Salend, 2011; Centre for Studies on Inclusive Education [CSIE], 2011, Wah, 2010;) farklı olsa da ülkemizde aynı kavram olarak ele alınmaktadır (MEB, 2018).

Kaynaştırma, genel olarak "özel gereksinimli olan ve olmayan tüm bireylerin genel eğitim sınıflarında, gerekli düzenlemeler ve uyarlamalar yapılarak birlikte eğitim almaları" olarak tanımlanmakta (Acarlar, 2013. s. 21) ve en az kısitlayıcı ortamda uygulanması gerekliliği üzerinde durulmaktadır (Diken ve Batu 2010, s.6).

Kapsayıc1/bütünleştirilmiş eğitim, “öğrenmeye, kültürlere ve topluluklara katılımı arttırmak ve eğitimden dışlanmayı azaltmak yoluyla tüm öğrencilerin gereksinimlerinin çeşitliliğini ele alma ve bunlara cevap verme süreci" olarak tanımlanmaktadır (UNESCO, 2009). Kapsayıcı eğitimde din dil, ırk, kültür, cinsiyet, cinsel yönelim, sosoyo-ekonomik düzey, coğrafi konum, engellilik vb. konularda bireysel farklılıkları olan "tüm öğrenciler" evrensel tasarım ilkesiyle düzenlemeler yapılır (Salend, 2016; s.1). Türkiye'de araştırmalarda ve yasalarda birlikte ele alınan kaynaştırma ve bütünleştirme arasındaki farklara aşağıda yer verilmiştir. 
Tablo 1: Bütünleştirme ve kaynaştırma arasındaki farklar (Salend, 2011'den faydalanılmıştır)

\begin{tabular}{|c|c|c|}
\hline Bütünleştirme & & Kaynaştırma \\
\hline $\begin{array}{l}\text { - Bütün öğrencilerin genel eğitim } \\
\text { sınıflarında eğitim alma hakları } \\
\text { vardır. }\end{array}$ & Kim & 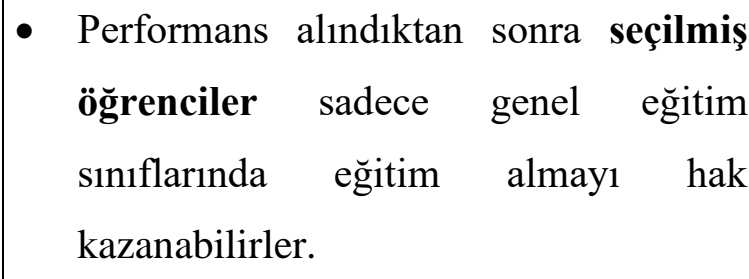 \\
\hline $\begin{array}{l}\text { - Genel eğitim programına ve } \\
\text { bütün öğretimsel ve sosyal } \\
\text { aktivitelere erişim hakları vardır. }\end{array}$ & $\mathrm{Ne}$ & $\begin{array}{l}\text { - Genel eğitim programına ve öğretimsel } \\
\text { ve sosyal aktivitelere sınırlı düzeyde } \\
\text { erişim hakları vardır. }\end{array}$ \\
\hline $\begin{array}{l}\text { - Tam zamanlı genel eğitim } \\
\text { sinıflarına } \\
\text { yapılır. }\end{array}$ & $\begin{array}{l}\text { Nerede } \\
\text { Ne } \\
\text { zaman }\end{array}$ & $\begin{array}{l}\text { - Genel eğitim sınıfına tam zamanlı ve } \\
\text { yarı zamanlı olacak şeklide iki farklı } \\
\text { uygulamayla sınıf ortamına yerleştirme } \\
\text { yapılmaktadır. }\end{array}$ \\
\hline $\begin{array}{l}\text { - Öğrencileri toplumla uyum } \\
\text { sağlayabilecek düzeye getirmek } \\
\text { için; tüm öğrencilerin } \\
\text { davranışsal, sosyal, akademik, } \\
\text { duygusal ve fiziksel gelişimlerine } \\
\text { odaklanılır. }\end{array}$ & Niçin & $\begin{array}{l}\text { - Öğrencileri topluma uyum sağlayacak } \\
\text { boyuta getirmek için; akademik, } \\
\text { davranışsal, sosyal, duygusal ve fiziksel } \\
\text { gelişimlerine odaklanılır. }\end{array}$ \\
\hline $\begin{array}{l}\text { - Destek hizmetler genel eğitimin } \\
\text { verildiği sinıflarda öğrencilere } \\
\text { sunulur } \\
\text { - Genel ve özel eğitim destek } \\
\text { hizmetleri birlikte verilir. }\end{array}$ & Nasıl & $\begin{array}{l}\text { - Destek hizmetler genel eğitim } \\
\text { ortamlarında ya da dışında (destek } \\
\text { eğitim odalarında) sunulur. } \\
\text { - Genel ve özel eğitim hizmetleri ayrı } \\
\text { hizmet sunumu birbirinden ayrı olarak } \\
\text { yapılandırılır. }\end{array}$ \\
\hline
\end{tabular}


$\mathrm{Bu}$ iki tanımı ve aralarındaki farkları net olarak belirtmek, ÖGB'lere sağlanacak DH'lerin verimliliği açısından oldukça önemlidir. Risk altında olan ve ÖGB'ler için Türkiye'de sağlanan DH'lerin Destek Eğitim Hizmetleri ve Sosyal ve Ekonomik Destek Hizmetleri olarak iki başlık altında toplandığı görülmektedir. Sosyal ve Ekonomik Destek Hizmetleri (SED): SED, risk gurubunda olup temel ihtiyaçlarını karşılayamayan ve hayatını sürdürmekte güçlük çeken çocuk ve gençlerin bakımı konusunda ailelerin desteklenmesi amacıyla verilen hizmetlerdir. Geçici ve sürekli ekonomik desteğini ve bu konuda bireye ve bireyin ailesine verilen bilgilendirmeleri, bakım tedbirlerini, aile içi sorunlarını çözme desteğini, risk altındaki kişi ve ailenin icra edecekleri mesleki bilgilendirmelerini, toplumsal kaynaklardan faydalanma konusundaki rehberliği kapsamaktadır [Aile ve Sosyal Politikalar Bakanlığı (ASPB), 2015].

Destek Eğitim Hizmetleri/Özel Ĕgitim Destek Hizmetleri: Özel gereksinimi olan bireylerin tıbbî ve eğitsel değerlendirme ve tanılama sürecinden sonra belirlenen öğrencinin bireyselleştirilmiş eğitim ihtiyaçları doğrultusunda ÖGB'lerin kendilerine, ailelerine, öğretmenlerine ve okul personeline sağlanan uzman personel, araç-gereç, eğitim ve danışmanlık hizmetleri olarak tanımlanmaktadır. Türkiye'de özel eğitim destek hizmetleri (ÖEDH) genel olarak okul içi ve okul dışı destek hizmetler olmak üzere ikiye ayrılır (MEB, 2018; Kış, 2013).

Okul dışı ÖEDH'nin verildiği özel eğitim ve rehabilitasyon merkezleri (ÖERM) 2007 yılında 5378 sayılı Kanun ile Milli Eğitim Bakanlığına devredilmiş ve anılan merkezler MEB çatısı altında okullara destek amaçlı bir kavrama dönüştürülmüşs (Cavkaytar, 2013). Türkiye'de DEH'lerin sağlandığı özel özel rehabilitasyon merkezlerinin bazı sorumlulukları özetlenmiştir: ÖGB’leri, özel yöntem, teknik donanım, personel ve eğitsel materyalleri kullanarak, ÖGB'lerin yetenek ve ilgileri doğrultusunda hayata hazırlanmalarını sağlar. Aynı zamanda bu kurumlar ÖGB'lerin toplum içindeki rollerini gerçekleştirmesinde, başkaları ile iyi ilişkiler kurabilmesinde, iş birliği ve uyum içinde çalışabilecek vatandaşlar yetiştirilmesinde yardımcı olabilecek özel eğitim desteği sunar. Bunu kısa sürede gerçekleştirmek için de birtakım düzenlemeler ve aile eğitimleri yapar, öğrenciler için diğer kurumlarla [okul, rehberlik araştırma merkezi (RAM), Sivil Toplum Kuruluşları (STK) vb.] işbirliği yapar (Keser ve Kış, 2019; MEB, 2018 Palas-Karaca, Başgöl, Cangöl, Aslan ve Cangöl, 2016). 
ÖERM'lerde ÖGB'in gereksinimlerine uygun şekilde en fazla ayda 8 saat bireysel(haftada 2 saat), ayda 4 saat grup (haftada 1 saat) olması şartıyla ayda toplam 12 saat seans eğitiminden yararlanabilmekte ve bunun karşılığında özel eğitim desteği olarak ortaya çıkan bütçe, MEB tarafından karşılanmaktadır (Cavkaytar, 2013). Buna ek olarak alınacak DEH ise aile tarafindan ödenmek zorundadır.

MEB’e bağlı örgün eğitim kurumlarında ise destek eğitimin verilmesi ile ilgili Destek Eğitim Odası Açılması Genelgesi hükümleri doğrultusunda yürütülmektedir. Bakanlığımızca ÖGB'ler için bütün kademe ve kurumlarda DEH'lerin verilmesi gerektiği belirtilmektedir (MEB Özel Eğitim ve Rehberlik Hizmetleri Genel Müdürlüğü, 2015). İlgili yasalar dahilinde özel gereksinimli bireylerin eğitim hakları güvence altına alınmış gibi görülse de bireyler DEH'e çoğunlukla ayrıştırılmış ve denetimsiz ortamlarda ulaşılabilmektedir.

Örgün eğitim kurumlarında ve özel eğitim ve rehabilitasyon kurumlarında sunulan destek eğitim hizmetlerinin niteliği hakkında yapılmış araştırmalar ise başta öğretmen yeterliklerinin önemli olduğunu göstermektedir (Uçar-Rasmussen ve Kış 2018; Karasu ve Mutlu, 2014). Öte yandan MEB, 2017 yılında öğretmenlerin genel yeterlilikleri konusunda birtakım güncellemeler yapmış ancak öğretmenlerin özel alan yeterliliklerine yönelik güncel bir çalışma yürütmemiş̧tir. 24.07.2008 tarihli ve B.08.0.0EG.0.13.01.04 sayıl1 genelgede ÖGB'lere yönelik gezerek özel eğitim görevi yapan özel eğitim öğretmenlerinin özel alan yeterliliklerine yer verilmiştir. Bu yeterlilikler; İletişim ve sosyal beceri yeterlilikleri, öğretim programını uyarlama yeterlilikleri, okul, aile ve diğer meslek alanları ile işbirliği yapma yeterlilikleri, davranış yönetimi yeterlilikleri, mesleki gelişimi sağlama yeterlilikleri olarak özetlenebilir.

Alanyazında ise öğretmenlerin söz edilen yeterlilik alanlarıyla ilgili farklı çalışmalara da rastlanmıştır. Bu çalışmalarda genel olarak öğretmenlerin yaşadığı sorunlar şu şekilde belirtilmiştir: Öğretmenlerin DEH konusunda eğitim almadan mezun oldukları, BEP'i sistematik olarak hazırlama ve uygulamada, öğretim yöntemini belirlemede ve yöntemi uygulamada, problem davranışlarla başa çıkmada, akademik ve sosyal becerilerin öğretiminde, öğrenciyi değerlendirmede sınırlılık, ailelerle işbirliği kurmada sorun yaşadıkları, cinsel eğitim vermede, materyal oluşturma ve uygun materyali kullanmada çözüm odaklı kurumlarla RAM iletişim kurmada, problem yaşadıkları dile getirilmiştir 
(Eldeniz-Çetin ve Şen, 2017; Gürgür, Büyükköse ve Kol, 2016; Palas-Karaca ve diğerleri, 2016; Sivrikaya ve Yıkmış, 2016).

Yapılan çalışmaların öğretmenlerin özel eğitim alan yeterlilikleri, bilgi düzeyleri, yaşadıkları sorunlar konusunda şekillendiği görülmektedir. Ancak öğretmenlerin bütünleştirme kapsamında sunulması gereken DEH sunma yeterlilikleri konusunda herhangi bir çalışmaya rastlanmamıştır.

\section{Amaç}

Bu araştırmanın temel amacı; özel eğitim okulları, RAM'lar ve rehabilitasyon merkezlerinde çalışan öğretmenlerin DEH'leri ÖGB'lere sunmadaki yeterliliklerinin ele alınması karşılaştırılmasıdır. Bu genel amaca ulaşmak için şu sorulara yanıt aranmıştır:

1. Öğretmenlerin destek hizmeti sunarken formasyon eğitimleri açısından yeterlilik düzeyi nedir?

2. Öğretmenlerin destek hizmeti sunarken özel eğitim alan yeterlilikleri açısından yeterlilik düzeyi nedir?

3. Öğretmenlerin destek hizmeti sunarken uyarlama ve farklılaştırma konusundaki yeterlilik düzeyi nedir?

4. Öğretmenlerin destek hizmeti sunarken öğrenciyi değerlendirme konusundaki yeterlilik düzeyi nedir?

5. Öğretmenlerin denetleyebilme konusundaki yeterlilik düzeyi nedir?

6. Öğretmenlerin kurumlar arası koordinasyonu sağlamada yeterlilik düzeyi nedir?

7. Öğretmenlerin bütünleştirme konusunda tanımlanan farklılıklar konusundaki yeterlilik düzeyi nedir?

\section{Yöntem}

\section{Araştırmanın modeli}

$\mathrm{Bu}$ araştırma nitel bir araştırma, olarak desenlenmiş ve veri toplama tekniği olarak odak grup görüşmeleri tercih edilmiştir. Nitel araştırma, herhangi bir sosyal olgunun ya da bir durumunu kendine has boyutlarını doğal ortamda tümevarımcı bir bakış açısıyla ele alan, katılımcıların duygu, düşünce ve görüşlerini anlamak üzerine kurgulanan bir araştırma çalışması olarak açıklanmaktadır (Ersin ve Bayyurt, 2015, s 202). Sosyal bilimlerde ağırlıklı olarak tercih edilen bu yöntem ile konular derinlemesine irdelenir. (Seggie ve Bayyurt, 2015, s, 2) Odak grup görüşmeleri, 6-10 kişilik küçük gruplar için derinlemesine bilgi 
almaya yönelik tasarlanmış bir görüşme tekniği olarak tanımlanabilir (Ersin ve Bayyurt, 2015; s 203).

\section{Katılımcilar}

$\mathrm{Bu}$ araştırmanın katılımcıları Mardin ve İstanbul illerindeki RAM, ÖERM, özel eğitim uygulama okulları ve özel eğitim sınıflarında görev yapan öğretmenlerden oluşacak şekilde belirlenmiştir. Bütünleştirme uygulamalarında daha önce bahsedilen farklı dil, din, kültür vb. yer verildiği için, araştırmanın katılımcıları belirlenirken bu özellikler göz önünde bulundurulmaya çalışılmıştır. Mardin ilindeki 7 ÖERM'de çalışan 7 grup ve farklı okullarda çalışan 2 grupla görüşme yapıldıktan sonra veri doygunluğuna ulaşılmış ve veri toplama süreci sonlandırılmıştır. Elde edilen bu verileri destekleyip desteklemediğini belirlemek için ise, İstanbul iline bağlı 3 ilçedeki 1 eğitim uygulama okulu ve 2 ÖERM seçilmiştir. Bu okul ve kurumlarda toplam 3 grupla görüşme gerçekleştirilmiştir. Toplam 62 öğretmen ile görüşme gerçekleştirilmiştir. Katılımcıların demografik bilgileri aşağıdaki tabloda belirtildiği gibidir:

Tablo 2: Katılımcıların yaş ve cinsiyetleri

\begin{tabular}{lcc}
\hline Yaş & Kadın & Erkek \\
\hline $20-24$ & 4 & 6 \\
$25-29$ & 14 & 20 \\
$30-35$ & 8 & 8 \\
$40-45$ & 1 & - \\
$50-65$ & - & 1 \\
\hline Toplam & 27 & 35 \\
\hline
\end{tabular}

Bu araştırmaya katılanların 38'i erkek, 24'ü kadındır. Katılımcıların yaş dağılımı şu şeklidedir: 20-24 yaş aralığı 10, 25-29 yaş aralığı 34, 30-35 yaş aralığı 16, 40-45 yaş aralığ 1, 50-65 yaş aralığı 1 kişi olarak belirlenmiştir. Çalışmaya katılan öğretmenlerin çoğunlukla 25-29 yaşlarında oldukları tespit edilmiştir. 
Tablo 3: Katılımclların mezun olduğu alanlar

\begin{tabular}{lcc}
\hline Mezuniyet & Kadın & Erkek \\
\hline Psikolojik Danışmanlık ve Rehber Öğretmenliği & - & 2 \\
Zihin Engelliler Sınıf Öğretmenliği & 4 & 4 \\
Sınıf Öğretmenliği & 8 & 19 \\
Okul Öncesi Öğretmenliği & 6 & 2 \\
Çocuk Gelişimi & 2 & - \\
Fransızca Öğretmenliği & - & 1 \\
İngilizce Öğretmenliği & 1 & - \\
Fizyoterapi & - & 5 \\
Hemşirelik & 1 & - \\
Psikoloji & 1 & 2 \\
Sosyoloji & 1 & 1 \\
Felsefe & 2 & 1 \\
Kimya & - & \\
\hline
\end{tabular}

Araştırmaya katılan öğretmenlerin mezun oldukları bölümler ve sayıları şu şekildedir: Psikolojik Danışmanlık ve Rehber Öğretmenliği 2, Zihin Engelliler Sınıf Öğretmenliği 8, Sınıf Öğretmenliği 25, Okul Öncesi Öğretmenliği 8, İngilizce Öğretmenliği 1, Fizyoterapi 5, Psikoloji 3, Çocuk gelişimi 2, Sosyoloji 1, Felsefe 3, Kimya 1, Biyoloji 1 ve Fransızca Öğretmenliği 1'dir. Araştırma kapsamında kendileriyle görüşülen 8 zihin engelliler sınıf öğretmenlerinden sadece 1'i bulunduğu ÖERM'de koordinatör olarak çalışmaktadır. Geriye kalan 7 özel eğitim alan mezunu öğretmen, MEB'e bağlı okullarda görev aldığg ve ÖERM'lerde en fazla sınıf öğretmenliği branşından öğretmenlerin çalıştığ1 tespit edilmiştir.

Katılımcılara Türkçe bilmeyen öğrencilerle nasıl iletişim kurdukları ve öğrencilere DEH'ini ne şeklide sağladıkları/sağlayamadıklarını belirlemek amacıyla katılımcıların bildiği diller konusunda demografik bilgi toplanmıştır. Sadece Türkçe bilenlerin sayısının 8 olduğu görülmüştür. Araştırmaya katılan öğretmenlerden hiçbirinin Süryanice bilmediği ve öğretmenler arasında Süryani kökenli öğretmen olmadığı, bununla birlikte öğretmenlerinin bazılarının İngilizce, İşaret Dili, Zazaca, Kürtçe, Arapça, Fransızca Azerice dillerini bildikleri ifade edilmiştir (Tablo 4). 
Tablo 4. Katılımcıların bildiği diller

\begin{tabular}{lcc}
\hline Bildiği Diller & Kadın & Erkek \\
\hline Türkçe ve Kürtçe bilenlerin sayısı & 12 & 27 \\
Türkçe ve Arapça bilenlerin sayısı & 3 & 3 \\
Türkçe, Arapça ve İngilizce bilenlerin sayısı & 1 & - \\
Türkçe, Kürtçe ve İngilizce bilenleri sayısı & 2 & 1 \\
Türkçe, Kürtçe, İngilizce ve İşaret dilini bilenleri sayısı & - & 1 \\
Türkçe ve Zazaca bilenlerin sayısı. & 1 & - \\
Türkçe, Azerice ve İngilizce bilenleri sayısı & - & 1 \\
Türkçe ve Fransızca bilenlerin sayısı & - & 1 \\
Sadece Türkçe bilenleri sayısı & 8 & 1 \\
\hline
\end{tabular}

\section{Ortamlar}

ÖERM ve okullardaki görüşmeler yapılmadan önce yetkili kişiler ile görüşülmüş ve odak grup görüşmeleri için uygun ortamlar belirlenmiştir. Ortamlar seçilirken görüşmeye katılan öğretmen ve araştırmacıların sayısına dikkat edilmiştir. Seçilen ortamların sessiz olmasına dikkat edilmiş, Mardin ilinin sıcak olması nedeniyle seçilen ortamlarda klima olmasına özen gösterilmiştir. Verilerin dökümü esnasında gerekli kolaylığı sağlaması için görüntü ve ses kayıt cihazları uygun şekilde yerleştirilmiştir.

\section{Veri toplama araçları}

Araştırma verileri, odak grup görüşme tekniği ile toplanmıştır. Araştırmacı bu aşamada alanyazın taraması yaparak hem kurumlarda hem de okullarda görev yapan öğretmenler için ayrı ayrı görüşme soruları oluşturmuştur. ÖERM/Okullarda Sağlanan Özel Eğitim Destek Hizmetleri Belirleme Formu (Ek 1), Öğretmen Kişisel Bilgi Formu (Ek 2), Okullarda Görev Yapan Öğretmenler için Sorular Formu (Ek 3) ve ÖERM’lerde Görev Yapan Öğretmenler için Sorular Formu (Ek4) geliştirilmiştir. Görüşme formlarındaki soruların uygunluğu ve anlaşılırlığı açısından üç uzman tarafından incelenmiştir. Pilot uygulamadan sonra sorular bir uzmanlar tarafindan tekrar değerlendirilerek düzenlenmiştir. 


\section{Verilerin toplanması}

Araştırma verileri Mardin ve İstanbul'daki 1 Özel Eğitim Uygulama Okulu ve 9 ÖERM'deki 62 öğretmenin katıldığ112 odak gurup görüşmesi sonucunda toplanmıştır. Görüşmeler görüntü ve ses kayıt cihazlarıyla kayıt altına alınmış, görüşme ortamında tedbir amaçlı yedek teknik ekipmanar bulundurulmuştur. Görüşme öncesi ilgili kişilere ve katılımcılara araştırma etik kurul onay belgesi (Ek 6) gösterilmiş, görüşmenin amacı açıklanmış ve öğretmenlerle sözleşme imzalanmıştır (Ek 5). Görüşmeler tez danışmanı ve araştırmacı tarafından birlikte yürütülmüştür. Saha notlarını tutmaları için ayrıca 2 özel eğitimci de görüşmelerde yer almıştır.

Veriler toplanırken kurum ve katılımcı kimliklerinin gizli tutulması nedeniyle verilerin analizinde kodlar kullanılmıştır. Yapılan kodlama ise şu şekildedir: Kurumun baş harfi ile birlikte cümle numarası Times New Roman Kalın stiliyle yazılmıştır. Örneğin, Y5, U19, S21 gibi. İstanbul'daki kurumlar için ise kurum kodunun başına İ yazılmıştır. Örneğin; IM14, İA18, İD26. Ayrıca verilen bulgunun sonunda görüşme dökümlerinin kaçıncı sayfada ve hangi ile ait olduğu da ( İstanbul için i. Mardin için m.) belirtilmiştir. Örneğini; (i. görüşme dökümleri s. 1), (m. görüşme dökümleri s. 20) gibi.

\section{Verilerin analizi}

Araştırma verilerinin analizinde nitel araştırma yöntemlerinde kullanılan analiz tekniklerinden betimsel analiz kullanılmıştır. Betimsel analizde, görüşülen ya da gözlenen bireylerin görüşlerini çarpıcı bir biçimde yansıtmak amacıyla doğrudan alıntılara sık sık yer verilir. Bu tür analizde amaç, elde edilen bulguları düzenlenmiş ve yorumlanmış bir biçimde betimlemektir. Daha sonra yapılan betimlemeler açıklanır ve yorumlanır, neden-sonuç ilişkileri irdelenir ve birtakım sonuçlar elde edilir. Ortaya çıkan temaların ilişkilendirilmesi, anlamlandırılması ve ileriye yönelik çıkarımlarda bulunulması da, araştırmacının yapacağı yorumların boyutları arasında yer alabilir (Yıldırım ve Şimşek, 2006).

$\mathrm{Bu}$ araştırmada görüşmeler tamamlandıktan hemen sonra uygun sessiz bir ortama geçilip dört kişinin tuttuğu saha notları karşılaştırılıp aktarımı sıcağı sıcağına yapılmıştır. Bu süreçte saha notlarını tutan kişilerle veri teyidi yapılmıştır. Veri kaybını önlemek için kamera kayıtları izlenip aktarımlar desteklenmiştir. Görüşme dökümleri biter bitmez uzman tarafindan veriler teker teker okunup verilerin doğruluğu kontrol edilmiştir. O esnada araştırmacı, araştırma günlüğ̈nü yazmıştır. Elde edilen tüm veriler temalar oluşturularak analiz edilmiştir. Bu doğrultuda oluşturulan temalar bulgular başlığı altında ele alınmıştır. 


\section{Bulgular}

Bu çalışmanın bulguları 423992 no’lu ve “Özel gereksinimli bireylerin aldıkları destek hizmetlerin bütünleştirme uygulamaları açısından incelenmesi” başlıklı tez için toplanan ve tez sürecinde dışarıda bırakılan verilerin yeniden analiz edilmesiyle oluşturulmuştur.

Yapılan alanyazın taramaları sonucu bu konuda yapılmış bir çalışmaya rastlanmamıştır. Bu nedenle araştırmanın bulguları güncelliğini korumaktadır.

Araştırmanın verilerinin analiz edilmesi sonucu ön plana çıkan temalar aşağıda belirtilmiştir.

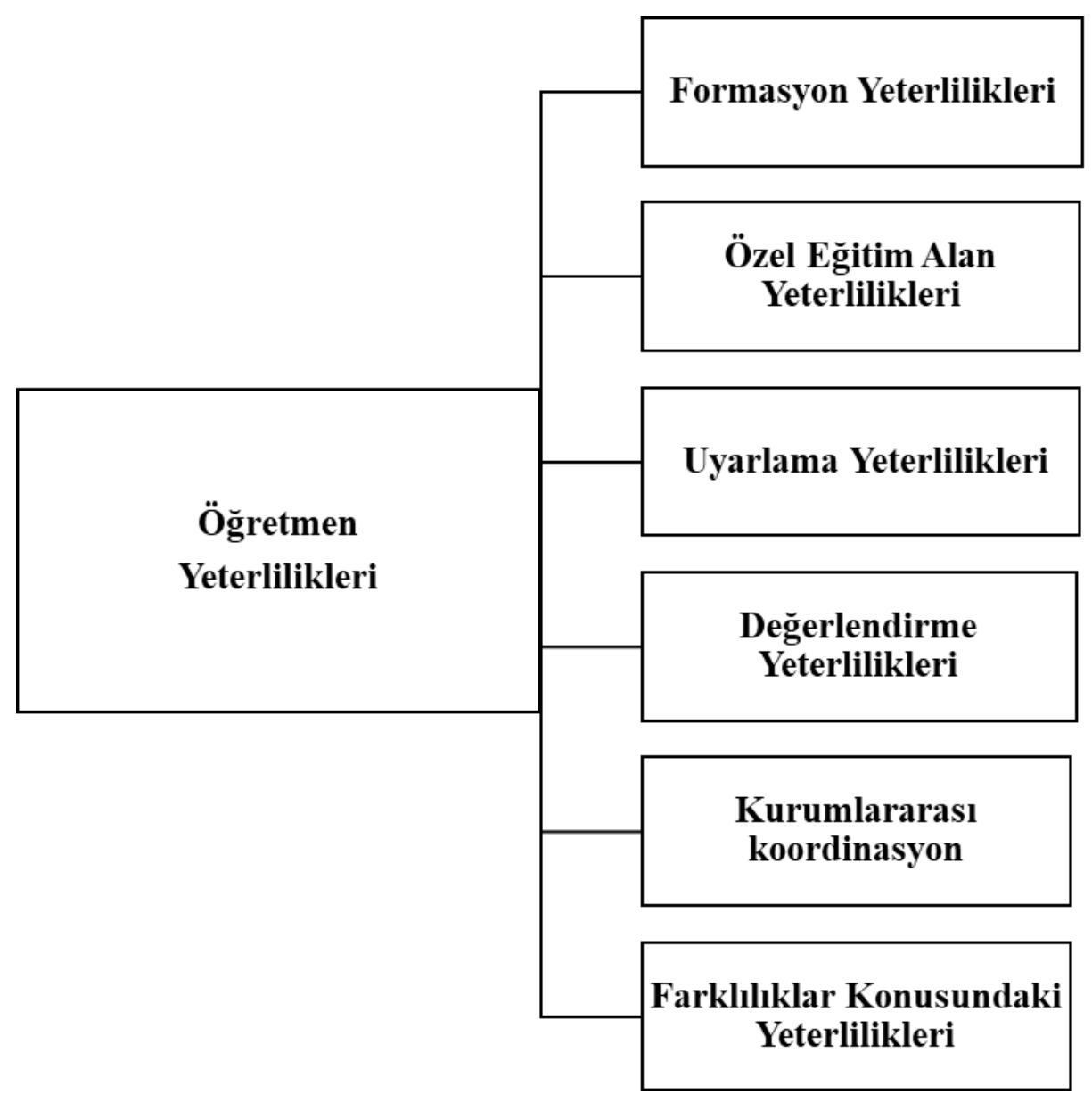

Şekil1. Verilerin analiz edilmesinden sonra oluşan temalar

\section{Öğretmenlerin pedagojik formasyon yeterlilikleri}

Öğretmenlerden pedagojik formasyon konusunda elde edilen bulgular aşağıda belirtildiği gibidir:

“Grup eğitimleri lise mezunları tarafindan veriliyor.” I15 (m. görüşme dökümleri s. 4). Özel gereksinimli bireylere sağlanan rehabilitasyon merkezlerindeki eğitim de sanki bir lütufmuş gibi bakılıyor. ’B7(görüşme 
dökümleri s. 10). “Atanma olmadiğı için burada çalışıyoruz.” Y2 (m. görüşme dökümleri s. 12). “Aile çocuğa sözünü geçiremiyor. Bize söylüyor biz çocuğu yönlendiriyoruz. Ancak kadrolu olmadığımız için sözümüz geçerli değil yine de.”Y13 (m. görüşme dökümleri s. 3).

Öğretmenlerin pedagojik formasyon konusundaki bulgulara bakıldığında, ÖERM'lerde çalışan öğretmenlerin öğrencilere, velilere nasıl davranacakları konusunda yeterli formasyon bilgilerinin olmadığı, ataması yapılmayan öğretmenlerin önemsenmediği görülmektedir. Benzer ifadeleri $\boldsymbol{I D}$ ve $\mathbf{I} \mathbf{M}(i$. görüşme dökümleri s. 10-11), kodlu kurumlarda çalışan öğretmenler de dile getirmiştir.

\section{Öğretmenlerin özel eğitim alan yeterlilikleri}

Öğretmenlerin özel eğitim alan yeterlilikleri ile ilgili elde edilen bulgular aşağıdaki belirtilmiştir:

“... Kaynaştırma öğrencisinin tepkilerini anlayacak kadar özel ĕgitim bilgimiz yok. Kaynaştırma öğrencisi, sınıfta problem davranış sergilediğinde bir şey yapamıyoruz. Bu nedenle sınıfin düzenini bozuyor ve neticede sinıfta istenmeyen ögrenci oluyor. ” E15 (m. görüşme dökümleri s. 25). "Kaynaştırma öğrenci için yapmamı gereken birçok şeyin olduğunu düşünüyorum ama ne yapacağımızı bilmiyorum. Yeni atanan ve bu dersi alan ögrretmen arkadaşlardan bilgi almaya çalışıyorum ama uygulamada yine sıkıntılar yaşıyorum.” E16 (m. görüşme dökümleri s. 25). "Birçok yerde alan mezunu özel eğitimci oldukça az.. B2 (görüşme dökümleri s. 10). "Değişik alanlarda mezunuz. Özel eğitim alanında mecburi olarak çalışlyoruz. H22 (m. görüşme dökümleri s. 12) Alan mezunları bizi eleştiriyor ama biz onlardan daha iyi çalışıyoruz. Yarın öbür gün özel ĕgitimciler sınıf ögretmeni olarak atanırsa şaşırmayın. H23 (m. görüşme dökümleri s. 12). “...RAM’larda nitelikli eleman yetersizliği var. Özellikle alan mezunu olan öğretmen sayısı çok az. Bu da bizi olumsuz etkiliyor...” IM74 (i. görüşme dökümleri s. 9). "Özel ĕgitim alanından mezun olmama rağmen kendimi yetersiz görüyorum.” IM76 (i. görüşme dökümleri s. 10). şeklinde olmuştur.

Benzer ifadeleri $\boldsymbol{B}$ ve $\boldsymbol{S}$ (m. görüşme dökümleri s. 10, 13) kodlu kurumlarda çalışan öğretmenler de dile getirmişlerdir.

Öğretmenlerin özel eğitim alanı konusundaki yeterlilikleri konusunda elde edilen bulgulara bakıldığında, öğretmenlerin kaynaştırma öğrencisi konusunda yetersiz kaldıkları, Özel 
eğitim alanından mezun olan öğretmenlerin de uygulamada yetersiz kaldıkları, ÖERM'lerde çalışan öğretmenlerin büyük bir kısmının diğer bölümlerde mezun olmuş ve atamaları yapılmayan öğretmenlerden oluştuğu ve bunun doğal sonucu olarak özel gereksinimli bireyler konusunda yetersiz kaldıkları görülmektedir. Ayrıca RAM'larda çalışan öğretmenlerin özel eğitim alan bilgilerinin yetersiz olmasından kaynaklı olarak değerlendirmeleri yanlış yaptıkları belirtilmiştir.

\section{Öğretmenlerin BEP, BÖP ve aile ĕgitim programı planlama yeterlilikleri}

Öğretmenlerin planlama konusundaki yeterlikleri ile ilgili elde edilen bulgular şu şekildedir:

“...Çocuk için faydall olacak amaçtan çok veli ne isterse onu yapmaya çalışıyorlar. Ben çocuğun kaslarının zayıf olduğunu biliyorum ona göre çalışlyorum ama veli okuma-yazma öğretmemi istiyor yani asıl sorun paralı olan velinin ne istediği oluyor." İM69 (i. görüşme dökümleri s. 9). benzer ifadeleri $\boldsymbol{H , C}$ (m. görüşme dökümleri s. 13,16), $\dot{\boldsymbol{I} A}, \mathbf{I} \boldsymbol{M}$ (i. görüşme dökümleri s. 16, 9) kodlu öğretmenler de dile getirmiştir.

Öğretmenlerin planlaması konusunda elde edilen bulgular incelendiğinde; genel eğitim veren öğretmenlerin özel gereksinimli bireylerin BEP'lerini önemsemedikleri, ÖERM'lerde çalışan öğretmenlerin BEP hazırlamak yerine RAM tarafından gönderilen BEP'leri baz aldıkları görülmektedir. Bununla birlikte bazı ÖERM'lerdeki öğretmenlerin öğrencinin BEP'indeki amaçları işlemdekileri, daha çok ailenin istediklerine göre ders işledikleri görülmektedir.

Öğretmenlerin öğretim yöntem ve teknikleri, problem davranış săgaltımı, ergenlik dönemi problemleri ile başa çıkama yeterlilikleri

Katılımcıların öğretimlerde kullandıkları öğretim yöntem ve teknikleri ile problem davranış sağaltımı ve ergenlik dönemi problemleri konusunda görüşleri şunlardır:

“...Bu yöntemleri bilenlerin çoğunu uygulamaya geçiremediğini görüyoruz. Şiddet olarak 'ses ’in bizde kalmadığını görüyoruz.” IM37

(i. görüşme dökümleri s. 5). Ergenlik dönemindeki bireyler için cinsiyet konusunda uyarlama yapılmıyor. Y15 (i. görüşme dökümleri s. 22). “...zamanla bildiğimiz doğrulardan uzaklaşarak ailenin istediğ $i$ egzersizleri yapıyoruz. Bile bile yararsız olanı çocuk için yapmaya başlıyoruz” H29 (m. görüşme dökümleri s. 13). “... Bazen kaynaştırma 
F.Keser ve A.Tanrıverdi/ Pamukkale Üniversitesi Eğitim Fakültesi Dergisi, 53, 328-354, 2021

ögrencisinin tepkilerini de anlamıyoruz. Problem davranış sergilediğinde bir şey yapamıyoruz....” E15 (m. görüşme dökümleri s. 4). “Bazı erkek ögrenciler de kadınlarl otorite olarak görmüyorlar. Öğrenci beni dikkate almıyor. 'Levent Hocayı çağırırım.' dediğimde o zaman dikkate alıyor." H35 (m. görüşme dökümleri s. 22). İ 19 (i. görüşme dökümleri s. 17). “... ögrretilen yöntem ve tekniklerin bir noktadan sonra işe yaramayacă̆ını uygulamaya başlayınca ve öğretmenliğe başlayınca gördük.” IM36 (i. görüşme dökümleri s. 5)

Yukarıdaki bulgulara benzer ifadeler IM33, (i. görüşme dökümleri s. 4,8 ve 9), $\boldsymbol{H}$ ve K(m. görüşme dökümleri s. 4, 18).)kodlu kurumlardaki öğretmenler tarafından da dile getirilmiştir.

Bulgular genel olarak özetlendiğinde; öğretmenlerin öğretim yöntem ve teknik çeşitliliği bilmedikleri, bilenlerin de uygulayamadıkları, öğrenciye ve BEP'teki amaca uygun yöntem ve tekniklerden çok velilerin istediği yöntem ve teknikleri uyguladıkları, problem davranış sağaltımı konusunda yeterli olmadıkları görülmektedir. Ayrıca problem davranış gösteren öğrencilerin daha çok erkek öğretmenlere verildiği, cinsel eğitim ve LGBT'lilerin eğitimi konusunda yetersiz oldukları da görülmektedir. Ayrıca özel eğitim alanından mezun öğretmenlerin yöntem ve teknik çeşitliliğini bilseler dahi uygulamada sınırlılık yaşadıkları belirtilmiştir.

\section{Öğretmenlerin aile ĕğitimleri, ailelerle iletişim yeterlilikleri}

Özel gereksinimli bireylerin aileleriyle iletişim ve aile eğitimleri konusunda elde edilen bulgular şunlardır:

“...Aile ĕgitimleri akşam 5'ten sonraya konulduğu için aile ĕgitimleri yapılamıyor. $I 11$ (m. görüssme dökümleri s. 4).

Benzer ifadeler $\mathbf{S}, \mathbf{U}, \mathbf{H}$ ve $\mathbf{C}$ kodlu ÖERM'lerdeki öğretmenler tarafından da dile getirilmiştir.

“Anadillerini bildiğimiz aileler ile iletişime geçebiliyoruz. Fakat ana dillerini bilmeyen öğretmenlerin velileri öğretmenleri ile iletişime geçmiyorlar." İM58(i. görüşme dökümleri s. 7). Kürtçe bilmiyorum. Öğrenci ve veliyle iletişim kurarken sorun yaşlyorum. Kürtçeyi bilmediğim için velilerden tepki allyorum $\mathbf{H 4 2}$ (m. görüşme dökümleri s. 22). 
Benzer ifadeleri K, C, İD (m. görüşme dökümleri s. 12, 22, 33.), C (m. görüşme dökümleri s. 33) kodlu kurumlarda çalışan öğretmenler tarafından da dile getirilmiştir.

Genel olarak aile eğitimlerinin düzenlenmediği, düzenlenen aile eğitimlerin ise öğretmenle sınırlı kaldığı belirtilmektedir. Aileler ile iletişim kurulurken ailelerin ana dillerinin öğretmenler tarafından bilinmesinin iletişimi kolaylaştırdığı, öğretmenin aileler tarafından kabul edilebilirliğinin arttığı, ailelerin ana dillerini bilmeyen öğretmenlerin veliler tarafından dikkatte alınmadığı görülmektedir.

\section{Denetleyicilerin özel ĕğitim alan bilgisi yeterlilikleri}

Denetleyicilerin özel eğitim alan yeterlilikleri konusunda ulaşılan bulgular şunlardır;
Kurum denetimleri formalite ve sadece evrak kontrolü yapılıyor. Denetim ĕgitim kontrolü ya da denetlemesi yapılmıyor. Denetlemeyi yapan müfettişlerinin eğitim altyapıları yetersizdir, denetimin daha uzun süreli yapılması gerekiyor. S22 (m. görüşme dökümleri s. 13). "Denetimi yapanların alan bilgisinin yeterli olması gerekiyor” C33 (m. görüşme dökümleri s. 10).

Benzer ifadeleri ' $\boldsymbol{Y}, \boldsymbol{B}, \boldsymbol{K}$, (m. görüşme dökümleri s. 18, 29, 36) ve ID(i. görüşme dökümleri s. 11) kodlu kurumlarda çalışan öğretmenler dile getirmişlerdir. Gerek RAM gerek ÖERM ve gerekse de okullarda denetlememelerin yapılmadığ 1 , yapılan denetlemelerin sadece evrak için yapıldı̆̆ 1 , bunun da çalışma mesaisinde öğretmenlerde bir gevşemeye sebep olduğu, çalışma sistematiği açısından öğretmenden öğretmene göre değişen ikiliklerin yaşanmasına sebep olduğu belirtilmiştir. Ayrıca denetleyicilerin özel eğitim konusunda yeterli bilgi sahibi olmaması da elde edilen bulgular arasındadır.

\section{Öğretmenlerin teknolojik uyarlamalar konusundaki yeterlilikleri}

Teknolojik uyarlamalar hakkında öğretmenlerden elde edilen bulgular şunlardır; “... Materyallerden ziyade çocuğun yaşantılarını kullanıyorum. Teknolojiyi kullanma imkanımız yok. ” H11 (m. görüşme dökümleri s. 4).... Alternatif teknoloji kullanmıyoruz. $\boldsymbol{H} 4$ (m. görüşme dökümleri s. 7). “DVD ve bilgisayarı kullansak daha iyi olur. Teknoloji sınırlı.” ID3 (i. görüşme dökümleri s. 11). "Eski okulda akıllı tahta vardı, bu bana çok yardımcı 
oluyordu. Şu an yok ve kağıtlarla, çocuklar ile bireysel ilgilenmek, çocukların dikkatini çekmiyordu, eskiden çekiyordu. PC'de kullanabileceğimiz program olarak özel eğitim için yoktu fakat ilköğretim için olanı uyarlayarak kullanıyorduk.” IM6 (i. görüşme dökümleri s. 1).

IM7, IA1, $\mathbf{I} A 16$ (i. görüşme dökümleri s. 1, 15,16) ve (i. görüşme dökümleri C61 (m. görüşme dökümleri $s . \quad 33)$ kodlu kurumlardaki öğretmenler de bulguları desteklemektedir.

Öğretmenlerin teknolojiyi kullanma düzeylerinin birbirlerine göre farklılık gösterdiğgi; ÖERM'lerde çalışan öğretmenlerin teknolojiyi çok kısıtlı düzeyde uyguladıkları, okullarda çalışan öğretmenlerin teknolojiyi özel gereksinimli bireyler için uyarlayamadıkları görülmektedir. Öğretmenlerin teknoloji konusunda yaşadığı sorunların daha çok kendilerine sınırlı düzeyde sağlanan/sağlanmayan teknolojik DH'lerden kaynaklandığı görülmekledir.

\section{Öğretmenlerin formel ve informel değerlendirme konusundaki yeterlilikleri}

Öğretmenlerin bu konudaki görüşleri aşağıda belirtilmiştir:

Hiçbir zihinsel engeli olmayan, fakat dilden kaynaklı olarak yanlış tanılanan ögrencilerimiz var. Bu durum da ögrencinin problem davranış sergilemesine sebep oluyor. K16 (m. görüşme dökümleri s. 3). ...RAM çocuğun kültürüne göre dilinde göre uyarlama yapmadan üç beş dakikada değerlendirme yapmaya çalışıyor.” ID25 (i. görüşme dökümleri s. 13). Tanılama sorunu var. Raporda sadece bedensel yetersizlik yazıyor. Tamamen biz çocuğu değerlendirip ona göre tedavi süreci almıyor. Çocuğun ihtiyacı olduğu halde fizik tedavi alamıyor. (raporunda yazmıyor.) H9 (m. görüşme dökümleri s. 1). Çocuğun engeline göre modüllere amaç konulmuyor...K15 (m. görüssme dökümleri s. 2). "RAM'da çocuklara sürekli aynı amaçlar veriliyor.” C36 (m. görüşme dökümleri s. 1). ...”Bazı veliler bu RAM tarafindan verilen raporu istemiyorlar çocuklarının etiketlenmemesi için...E7 ((m. görüşme dökümleri s. 20).

Yukarıda yer verilen bulgular $\boldsymbol{Y}, \boldsymbol{C}$ (m. görüşme dökümleri s. ,337), $\mathbf{I D}$ ve $\dot{\boldsymbol{I} A 4}$ (i. görüşme dökümleri s. 13, 15) kodlu kurumlarda çalışan öğretmenler tarafindan da dile getirilmiştir.

Değerlendirme konusunda elde edilen bulgulara bakıldığında daha çok RAM'larda çalışan personelin bu konudaki nitelik sorunu ön plana çıkmaktadır. RAM tarafından 
öğrenciler için yazılan amaçların öğrencilerin engel ve akademik performans düzeyine uygun olmadığı, öğrenciler için aynı amaçların yazıldığı ve bu durumdan kaynaklı olarak öğrencilerin daha çok problem davranış göstermeye başladığı belirtilmiştir. Ayrıca RAM'daki personelin uyarlama yapmadan değerlendirme yaptığı/informal ya da dil ve kültüre dayalı değerlendirme süreçlerine yer verilmeden öğrenciyi değerlendirdiği bu durumun da etiketlemeye sebep olduğu belirtilmiştir.

\section{Personelin Kurumlar arası koordinasyon yeterlilikleri}

Okul, RAM ve ÖERM'lerde çalışan personelin birbirleriyle olan iletişimleri hakkında edilen bulgular aşağıda belirtildiği gibidir:

“...Geçen sene okul ziyaretine gittik, bizi almadılar bile. Bize ögretmen gözü ile bakmıyorlar ama kendi rahatlarını bozmak için de bizimle iletişime geçmiyorlar. Memur zihniyetiyle bakıyorlar duruma, mesaim bitsin de evimize gidelim mantığlyla bakıyorlar" $\dot{\boldsymbol{I} A 14}$ (i. görüşme dökümleri s. 16). DH’ler konusunda rehabilitasyon merkezleri ile iletişime geçmiyoruz. Yanlış ĕgitim verdikleri için ne desek nafile. Kalem tutmayı bilmeyen çocuğa “anne baba” yazdırmışlar.” IM68 (i. görüşme dökümleri s. 9. “..Müdürler daha çok rehabilitasyon merkezleri ile iletişime geçilmesine engel oluyorlar." iD22 (i. görüşme dökümleri s. 13)

S, Y, $\boldsymbol{K}$ (m. görüşme dökümleri s. 7, 13, 36) ve ID, $\boldsymbol{I} \boldsymbol{A}$ (i. görüşme dökümleri s. 13, 17) kodlu kurumlarda da benzer bulgular bulunmuştur.

Bulgulara genel olarak bakıldığında personelin özel gereksinimli öğrencileri için birbirleriyle iletişim kurmadıkları ve öğrenci için bilgi alışverişinde bulunmadıkları ayrıca özel eğitim okulları ve sınıflarında çalışan öğretmenlerin ÖERM'lerde çalışan öğretmenleri kendilerine denk görmedikleri ve özel eğitim konusunda kendilerini otorite olarak gördükleri görülmektedir.

\section{Personelin farklı dil, din, kültür ve cinsel yönelim konusundaki yeterlilikleri}

Araştırmaya katılan tüm öğretmenlerin en fazla üzerinde durduğu farklı dil din, kültür ce cinsel yönelim konusunda elde edilen bulgular aşağıda özetlenmiştir.

Dil farklılıkları yanlış tanılamaya sebep oluyor. Çocuk dil bilmediği için direk etiketlenmiş oluyor. C39 (m. görüşme dökümleri s. 
F.Keser ve A.Tanrıverdi/ Pamukkale Üniversitesi Eğitim Fakültesi Dergisi, 53, 328-354, 2021

21). Çocuğa Türkçe yönerge verdiğimizde çocuk anlamıyor, mecburen yönergeyi Kürtçe veriyoruz. $\mathbf{K} 8$ (m. görüşme dökümleri s. 35). Dil sorunu denetleme için de geçerlidir. Denetlemeye gelen kişi Kürtçe bilmediği için, onun gözünde çocuk hiçbir şey bilmemiş oluyor. Çünkü denetleme olduğunda çocuk ile Türkçe iletişime geçiyoruz. Bu defa da çocuk hiçbir şey anlamdan gözümüzü içine bakıyor. $\mathbf{K 1 0}$ (m. görüşme dökümleri s. 36). Geçen yıl öğrencimin annesi Türkçe bilmediği için iletişime geçemedik. Baba Türkçe biliyordu okula çağırdık o da gelmedi. Anne Türkçe bilmediği için iletişime geçemediğimiz için çocuğu kaybettik ve çocuğu okuldan aldılar. IM62 (i. görüşme dökümleri s. 6). “...Aileler RAM’a gittikleri zaman dertlerinin Türkçe anlatamıyor, RAM'da çalışan ögretmenler de ailenin konuştuğu dili bilmiyorlar. Bu da çocuğun yanlış tanılanmasına sebep oluyor.” C39 (m. görüşme dökümleri s. 21). “Türkçe bilmeyen çocuklarımı kuruma geldiklerinde Kürtçe bilen ögretmenlerimize yönlendiriyoruz. Öğretmenimiz çocuklarla Kürtçe daha rahat iletişim kurabiliyor. Ancak çocuğun sosyal kabul görmesi için daha sonra Türkçe iletişime geçiyoruz. Çünkü toplumun çoğu Türkçe konuşuyor." ID10 (i. görüşme dökümleri s. 11)

Bulgulara bakıldığında çocuğun ana dilini bilmeyen personelin çocuk ve aile iletişim kurmada zorlandıkları, dilden kaynaklı olarak yanlış performans aldıkları, bunun da birtakım sorunlara yol açtığı görülmektedir. Çocuğun ve ailenin ana dilini bilen personelin çocuk ve aile ile daha rahat kurduğu, çocuğun akademik gelişimine daha fazla katkı sağladıkları anlaşılmaktadır. Benzer bulgular $\boldsymbol{I} \boldsymbol{M}, \boldsymbol{I} \boldsymbol{D}$ (i. görüşme dökümleri s. 6, 12) ve $\mathbf{E}$ (m. görüşme dökümleri s. 39) kodlu kurumlardan da elde edilmiştir. öğretmenlerin farklı kültür din konusundaki ifadeleri ise şu şeklidedir:

"Farklıllklar üzerine üniversiteden herhangi bir ders almadık. Sadece 'Bireysel Farklıklar' diye bir ders aldık. IM59 (i. görüşme dökümleri s. 8) “Mezhepler konusunda herhangi bir uyarlama yok.”iD18 (i. görüşme dökümleri s. 12). “...kültür, dil ve din konusunda bir takım düzenlemelerin yapılması gerektiği, bu konuda sorunların yaşandığını söyleyebiliriz” B20 (m. görüşme dökümleri s. 42). 
Ayrıca öğretmenlerin farklı din, kültür ve cinsel yönelim konusunda uyarlama yapmadığı, yapılan uyarlamaların ise kısıtlı düzeyde olduğu görülmüştür. Bu uyarlamaların yapılmamasının öğretmen yeterlilikleriyle alakalı olmaktan çok bu konuda baskın din ve kültüre uyum sağlanmasından kaynaklı olarak ailelilerden bir talebin gelmemesinden kaynaklı olduğu belirtilmiştir.

\section{Tartışma}

Eğitim hakkının önem kazanmasıyla birlikte dünya eğitim sisteminde birtakım düzenlemelerin güncellenmesi kaçınılmaz olmuştur. "Herkes için eğitim” felsefesi temelinde bütünleştirilmiş eğitim kapsamında dezavantajlı ve özel gereksinimli bireylere sağlanan destek hizmetlerde de değişiklikler olmuştur. Bu destek hizmetleri özel gereksinimli bireylere başaralı bir şekilde sağlamak için de öğretmenin niteliği oldukça önemlidir. Öğretmen yeterliliklerini destek hizmetler kapsamında ele alan bu araştırmanın yöntemi nitel araştırma yöntemi olup araştırma bulguları odak grup görüşmeleriyle elde edilmiştir.

Araştırma kapsamında elde edilen bulguları özetlemek gerekirse; ÖERM'ler başta olmak üzere birçok özel eğitim kurumunda alan dışı öğretmenin çalıştığı, öğretmenlerin öğrencilere akademik beceriler öğretecek ve aile eğitimi verebilecek pedagojik formasyonlarının yetersiz olduğu, kaynaştırma öğrencisi başta olmak üzere özel gereksinimli bireylere kavram ve beceri öğretimi için gerekli olan özel eğitim bilgilerinin yeterli olmadığı, bu durumun özel eğitim kurumlarını denetleyenler için de geçerli olduğu, öğretmenlerin BEP ve BÖP'leri planlama, öğrencileri formal ve informal olarak değerlendirecek yetkinliklerinin olmadığı bulguları elde edilmiştir. Öğretmenlerin öğrencilerin problem davranışlarıyla baş edecek, kavram ve beceri öğretimi yapacak, aile ve cinsel eğitim verecek yöntem bilgilerinin yeterli ve güncel olmadığı bulgularına ulaşılmıştır. Bununla birlikte RAM'larda çalışan öğretmenlerin de testleri uygulayacak, öğrencilerin performanslarına uygun şekilde değerlendirecek yetkinliklerinin olmadığı, Ayrıca farklı dil, din, kültür ve cinsel yönelim konusunda öğretmenlerin farklılaştırma ve uyarlama yapacak yeterliliklerin olmadığ 1 görülmüştür. $\mathrm{Bu}$ nedenle öğrenciler ve ailelerle iletişim kurmada güçlük yaşadıkları ve aileler tarafından önemsenmedikleri bulgularına da ulaşılmıştır. Son olarak öğretmenlerin teknolojiyi uyarlamada zorlandıkları ve öğrenciye destek hizmetleri sağlamada gerekli kolaylığı sağlayacak personelle iletişimi kurmada zorlandıkları bulgularına ulaşılmıştır. 
$\mathrm{Bu}$ araştırmada elde edilen bulguların alanyazın ile paralellik gösterdiği görülmektedir. Örneğin Uçar-Rasmussen ve Kış (2018) tarafından gerçekleştirilen araştırmada, farklı branşlardan mezun olan ancak özel eğitim alanında çalışan öğretmenlerin planlama, değerlendirme, aile eğitimi ve öğrenci için işbirliği için gerekli donanıma sahip olmadıkları belirtilmiştir. Bununla birlikte özel eğitim alanında çalışan öğrtmenlerin temel özel eğitim (Yıkmış \& Özbey, 2009) ve formasyon alanlarında sınırlıklara sahip olduklarına ve sorunlar yaşadıklarına ulaşılmıştır (Altınkurt, 2008; Karasu ve Mutlu, 2014). Öğretmenlerin yaşadıkları bu sorunların ve bilgi yetersizliğinin ise öğrencilerin gelişimsel alanlarını etkileyen sorunlara ve sınıf yönetimi konusunda bazı olumsuzluklara yol açtığı belirtilmiştir (Weiss, Markowetz, ve Kiel, 2018). Ayrıca öğretmenlerin farklı yöntem ve tekniklere sahip olmaları gerektiği, öğrenciler için uygun BEP planlamada ve oluşturulan bu BEP'leri değerlendirmesinde zorlandıkları ve RAM'daki personel tarafından oluşturulan BEP'lerin öğrencilerin seviyelerine uygunluğu ile ilgili yapılan araştırmaların bulgularının alanyazın ile örtüştüğü görülmektedir (Al-Shammari ve Hornby 2020; Avcıŏglu, 2012).

Yukarıda belirtilenlerle birlikte, ÖERM'lerde çalışan öğretmenlerin uygulamalı aile eğitimi vermede zorlandıkları, ÖERM ve RAM'larda çalışan öğretmenlerin kurum içi ve kurumlar arası iletişimlerinin güçlü olmadığı (Tiryakioğlu, 2009; Korucu, 2005), öğretmenlerin cinsel eğitim verebilecek yeterliliklerin olmadığı bu nedenle bu konuda hizmetiçi eğitim almaları gerektiği belirtilmiştir (Karaca ve diğerleri 2016). Öte yandan ÖERM'lerde çalışan personelin özel eğitim konusunda gerekli donanıma sahip olmalarının önemli olduğu ifade edilmiştir (Sağırlığlu, 2006).

Denetleme ile ilgili elde edilen bulguların da alanyazın ile paralellik gösterdiği; denetimleri yapan kişilerin özel eğitim alan bilgilerinin yetersiz olduğu, denetimlerin daha çok evrak kontrolü şeklinde yürütüldüğü ancak özel eğitim müfettişlerinin genel eğitim müfettişlerinden farklı olarak özel eğitim yöntem ve tekniklerine hakim kişiler olması gerektiği belirtilmiştir (Zigmond, 2003).

Adaptasyon konusundaki bulguların da alanyazın ile örtüştüğü görülmektedir. Herkes için eğitim felsefesine dayanan ve bütünleştirme uygulamaları kapsamında da yer alan farkl1lıklara (dil, etnisite, inanç, sosyoekonomik düzey vb.) yönelik eğitim vermenin ve destek hizmeti sunmamın zor olduğu; bu nedenle öğretmenler tarafindan farklıklara yönelik öğretim stratejilerinin geliştirilmesinin, uygun teknolojinin sunulmasının ve çevre okullarla bu konularda işbirliği yapılmasının önemli olduğundan bahsedilmektedir (Nel, Tlale, 
Engelbrecht \& Nel, 2016).Yürütülen bu araştırmada en çok ön plana çıkan bulgulardan biri de ÖGB'lerin anadilden kaynaklı yaşadığı sorunlardır. Bu araştırmaya paralel olarak; değerlendirmelerin hem ana dil hem eğitim dilinde kapsamlı olarak yürütülmemesinden kaynaklı olarak çocukların, hiçbir yetersizliği olmamasına rağmen dilden kaynaklı olarak yanlış tanılandığı, ana dili resmi dilden farklı olan öğrenciler ile iletişim kurulmasında zorlanıldığ ve çocuğun ana diliyle iletişim kurulduğunda çocuğun daha kısa sürede yol aldığı, belirtilmiş̧tir (Baker, 2011; Karasu ve Mutlu, 2014; Rodríguez, 2015; Villages, 2019). Bunlara ek olarak aile bireylerinin ana dillerinde iletişim kurmanın, aile eğitimi düzenlemenin ÖGB'lerin akademik başarısını daha arttırdığı, aile katılımını da güçlendirdiği görülmüştür (Onorato 2016; Jegatheesan, Miller ve Fowler 2010).

\section{Sonuç}

Araştırmanın bulguları incelendiğinde şu sonuçlara ulaşılmıştır: Araştırmaya katılan ve ÖERM, RAM, Özel Eğitim Uygulama Okulu ve Özel Eğitim sınıflarında çalışan Özel Eğitim alan mezunu öğretmenlerinin sayısı oldukça azdır (\%12.9). ÖERM'lerde çalışan özel eğitim alan mezunu öğretmen sayısı ise \% 1.6'dır. Bunula birlikte özel eğitim öğretmenleri dahil olmak üzere öğretmenlerin öğrencilere beceri ve kavram öğretiminde, problem davranış sağaltımında, cinsel eğitim vermede, aile eğitimi düzenlemede ve ailenin ana diliyle iletişim kurmada, BEP ve BÖP planlamada, öğrencileri formal ve informal olarak değerlendirmede, teknolojiyi BEP’teki amaçlara göre uyarlamada zorlandıkları sonucuna varılmıştır. Ayrıca bütünleş̧irilmiş eğitim sisteminde farklı dil, din, kültür ve cinsel yönelim konusunda destek hizmetlerin sunulmasında oldukça zorlandıkları öte yandan öğrencinin ve ailenin ana dilini bilen öğretmenlerin öğrencilerin gelişimine daha fazla katkı sağladıkları sonucuna ulaşılmıştır.

Öğretmenlerin bütünleş̧irme uygulamaları kapsamında özel eğitim destek hizmetleri sunabilmeleri için yeterli düzeye getirilmeleri için öncelikle Özel Eğitim Hizmetleri Yönetmeliğinin güncellenmesi önerilmektedir. Yönetmelikte kaynaştırma/bütünleştirme olarak birlikte açıklanan kavramların dünya alanyazınında birbirlerinden farklı olduğu by nedenle bütünleştirme (inclusion), bütünleş̧irilmiş eğitim (inclusive education) kavramının kaynaştırma(mainstreaiming) kavramından ayrı olarak tanımlanması ve bütünleştire kapsamında sunulacak destek hizmetlerin net olarak tanımlanması gerektiği önerilmektedir. Yasada tanımlanacak bu destek hizmetlere yönelik hizmetiçi eğitimlerinin içeriklerinin güncellenesi önerilmektedir. Ayrıca planlama, değerlendirme, aile eğitimleri, cinsel eğitim, 
sınıf yönetimi, kavram ve beceri öğretimi, sosyal ve iletişim becerileri, ifade edici dil becerileri konusunda öğretmenlerin donanımlı hale getirilebilmesi için bilimsel dayanaklı kapsamlı müdahale programları da hizmetiçi eğitimlere dahil edilebilir.

Öte yandan ana dilleri farklı olan özel gereksinimli ve dezavantajlı çocukların okula başladıkları ilk dönemlerde eğitimin sadece resmi dil olan Türkçe üzerinden yürütülmesi nedeniyle zorlandıkları (Karasu ve Mutlu, 2014); alanyazında bu zorlukların minimum seviyeye indirmek için iki dilli özel eğitim uygulamalarının gerçekleştirildiği görülmektedir (Gampe, Wermelinger ve Daum, 2019; Bergroth ve Palviainen 2017; García ve Lin, 2017). Anadil eğitimi ya da geçiş modeli temelinde ele alınan iki dilli özel eğitim uygulamalarının gerçekleştirilmesi için yasada tanımlanan bütünleştirme uygulamalarına ek olarak farklı dil, din, kültür ve cinsel yönelime yönelik destek hizmetlerin sağlanmasının önünü açabilecek yasal düzenlemelerin yapılması önerilmektedir. Ayrıca üniversitelerin özel eğitim öğretmen yetiştirme programı kapsamında öğretimi yapılan bireysel farklılıklar dersine ek olarak insan hakları, farklı dil, din, kültür ve cinsel yönelim konusunda derslerin okutulabileceği önerilmektedir. İleriye dönük araştırmalar için ise, kaynaştırma ve bütünleştirmenin farklı kavramlar olarak ele alınması gerektiği, ana dil ile resmi dil üzerinden yapılacak uygulamaların karşılaştırmalı olarak incelenmesi gerektiği önerilebilir.

$\mathrm{Bu}$ araştırma kapsamında toplanan veriler öğretmenlerin düşünceleri ve verilerin toplandığı Mardin ve İstanbul ile sınırlıdır. Ayrıca ramazan ayının araştırma verilerinin toplandığı zaman dilimine denk gelmesi nedeniyle oruç tutan öğretmenlerin ile oruç tutmayan öğretmenlerle aynı anda odak gurup görüşmelerine dahil edilmek zorunda kalınması da bu araştırmanın bir diğer sınırlılı̆̆ıdır.

Etik Kurul İzin Bilgisi: Bu araştırma, Abant İzzet Baysal Üniversitesi Sosyal Bilimlerde İnsan Çalışmaları etik kurulunun 20/06/2014 tarihli 2014/60 sayılı kararı ile alınan izinle yürütülmüştür.

Yazar Çıkar Çatışması Bilgisi: Bu araştırma yürütülürken potansiyel olarak yazarların çıkarları göz önünde bulundurulmamıştır.

Yazar Katkısı: Araştırmanın fikir, dizayn, verilerin toplanması ve analiz edilmesi ve raporlaştırılması aşamalarında birlikte ve eşit katkı sağlamışlardır. 


\section{Kaynakça}

Acarlar, F. (2013). Kaynaştırma modeli ve özel gereksinimli çocukların özellikleri. Okul Öncesinde Kaynaştırma, 21-74.

Al-Shammari, Z., \& Hornby, G. (2020). Special education teachers' knowledge and experience of IEPs in the education of students with special educational needs. International Journal of Disability, Development and Education, 67(2), 167181.

Altınkurt, N. (2008). Özel eğitim ve rehabilitasyon merkezlerinde yaşanilan sorunlar ve çözüm önerileri. Unpublished master dissertation. Dokuz Eylül Üniversitesi Eğitim Bilimleri Enstitüsü, İzmir.

Armstrong, F. (2011). School cultures, teaching and learning. (Ed. G. Richards \& F. Armstrong). Teaching and learning in diverse and inclusive classrooms içinde (s. 118). Newyork: Routledge.

ASB, (2015) Sosyal ve ekonomik destek hizmetleri hakkında yönetmelik. [çevirim- içi: www.resmigazete.gov.tr/eskiler/2015/03/20150303-3.htm/l, Erişim tarihi: 12.09.2020.

Avcıoğlu, H. (2012). Rehberlik ve araştırma merkez (RAM) müdürlerinin tanılama, yerleştirme-izleme, bireyselleştirilmiş eğitim programı (BEP) geliştirme ve kaynaştırma uygulamasında karşılaşılan sorunlara ilişkin algıları. Kuram ve Uygulamada Ĕgitim Bilimleri, 12(3), 2009-2031.

Baker, C. (2011). Foundations of bilingual education and bilingualism. Multilingual matters: 2nd EditionBergroth, M., \& Palviainen, A.. (2017). Bilingual children as policy agents: Language policy and education policy in minority language medium Early Childhood Education and Care. Multilingua, 36(4), 375399.

Booth, T..\& Ainscow, M. (2002). Index for Inclusion: Developing Learning and Participation in Schools. Bristol: Centre for Studies on Inclusive Education. [çevirim-içi: www.csie.org.uk/publications/inclusion-index-explained.html.] erișim tarihi: 18.07.2020. 
Bryant, D., Smith, D., \& Bryant,, B. (2008). Teaching students with special needs:In inclusive classrooms. Boston, MA: Pearsons Education, Inc

Cavkaytar, A. (2013). Özel eğitime gereksinim duyan çocuklar ve özel eğitim. (Ed. İ.H. Diken). Özel eğitime gereksinimi olan ögrenciler ve özel ĕgitim içinde. Ankara: Pegem Yayıncilık.

CSIE, (2011). What is inclusion? [çevirim-içi://www.csie.org.uk/inclusion/what. Shtml], erişim tarihi:19.04. 2020.

Diken, İ. H. \& Batu, S. (2010). Kaynaştırmaya giriş. (Editörler İ. H. Diken \& S. Batu) İlköğretimde kaynaştırma, içinde (s. 2-23.)

Eldeniz-Çetin, M. \& Şen, S. G., (2017) Özel eğitim ve rehabilitasyon merkezlerinde çalışan ögretmenlerin sorunlarının belirlenmesi. International Journal of Social Science. Number: 59 , p. 53-69 Doi number:http://dx.doi.org/10.9761/JASSS7133

Ersin P. \& Bayyurt, Y. (Eds). (2015). Odak Grup Görüşmeleri. (Editörler F. N. Seggie \& Y. Bayyurt) Nitel araştırma: Yöntem, teknik, analiz ve yaklaşımları içinde (s.202218) Ankara: Anı Yayıncılık.

Gampe, A., Wermelinger, S., \& Daum, M. M. (2019). Bilingual children adapt to the needs of their communication partners, monolinguals do not. Child development, 90(1), 98107.

García, O., \& Lin, A. (2017). Extending understandings of bilingual and multilingual education. (Eds O. García A. M. Y. Lin \& S. May) Bilingual and multilingual education, 1-20. 3. Bask1. Springer.

Gürgür, H., Büyükköse, D., \& Kol, Ç. (2016). Özel eğitim ve rehabilitasyon merkezlerinde işitme kayıplı öğrencilere sunulan destek hizmetler: öğretmen görüşleri. Elementary Education Online, 15(4).

Jegatheesan, B., Miller, P. J., \& Fowler, S. A. (2010). Autism from a religious perspective: A study of parental beliefs in South Asian Muslim immigrant families. Focus on Autism and Other Developmental Disabilities, 25(2), 98-109. 
Karasu, T., \& Mutlu, Y. (2014). Öğretmenlerin perspektifinden özel eğitimde yaşanan sorunlar ve çözüm önerileri: Muş il örneği. Anemon Muş Alparslan Üniversitesi Sosyal Bilimler Dergisi, 2(1), 47-66.

Keser, F. (2016). Destek Hizmetlerin Bütünleştirme Uygulamaları Açısından İncelenmesi. Düsseldorf: Lambert: Almanya.

Keser, F. \& Tanrıverdi, A. (2019). Determining support services received by individuals with special needs living in mardin and İstanbul. The Journal of International Social Research, S. 12(62), 1058-1066

Kış, H. (2013). Destek eğitim odalarındaki uygulamalara ilişkin rehber öğretmenler ve özel eğitim sinıf öğretmenlerinin görüşleri. Unpublished master dissertation Abant İzzet Baysal Üniversitesi Eğitim Bilimler Enstitüsü, Bolu.

Korucu, N. (2005). Türkiye'de Özel Eğitim ve Rehabilitasyon Hizmeti Veren Kuruluşların Karşılaştığı Güçlüklerin Analizi: Kurulus Sahipleri, Müdür, Öğretmen ve Aileler Açısından. Unpublished master dissertation. Selçuk Üniversitesi, Sosyal Bilimler Enstitüsü, Konya.

MEB, (2020). Özel Eğitim Hakkinda Kanun Hükmünde Kararname ve Özel Eğitim HizmetleriYönetmeliği. Retrieved from https://orgm.meb.gov.tr/meb_iys_dosyalar /2020_06/24163215_ozel_eYitim_yonetmeliYi_son_hali.pdf on 25 March 2020.

MEB, (2018). Özel Eğitim Hakkinda Kanun Hükmünde Kararname ve Özel Eğitim Hizmetleri Yönetmeliği. [çevirim-içi:http://www.resmigazete.gov.tr/eskiler/20180 /20180707-8.htm.], erişim tarihi: 24.04.2020.

MEB, (2008). Milli Eğitim Bakanlığl Öğretmen Yetişstirme ve Eğitimi Genel Müdürlüğ̈̈8.03.2008 tarihli B.08.0.0EG.0.13.01.04-/1835 sayll genelgesi. [çevirim-içi:otmg.meb.gov.tr/belgeler/alanyeterlikler/ozelalan\%20yeterlikleri.pdf], erişim tarihi: 14.09. 2020. 
Nel, N. M., Tlale, L. D. N., Engelbrecht, P., \& Nel, M. (2016). Teachers' perceptions of education support structures in the implementation of inclusive education in South Africa. Koers,ISNN2304-8557 81(3),1-14. [çevirim-içi:http://dx.doi.org/10.19108 /koers.81.3.22 49.], erişim tarihi: 15.12.2020.

Onorato, P. G. (2016). Investigating the Effects of a Parent-Mediated Intervention on Latino Parent-Child Verbal Interaction and Children's Receptive Vocabulary. Unpublished doctoral dissertation. Virginia Commonwealth University, Richmond.

Palas-Karaca, P., Başgöl, Ş., Cangöl, E., Aslan, E., \& Cangöl, S. (2016). Özel eğitim ve rehabilitasyon merkezi çalışanlarının engelli bireylerin cinsel eğitimi konusundaki görüşleri. Balıkesir Sağlık Bilimleri Dergisi, 5(1), 13-17.

Rasmussen, M. U., \& Kış, A. (2018). Qualifications of subject teachers in special education schools. Journal of Education and Training Studies, 6(4), 48-57.

Rodríguez, D. (2015). Bilingual special education: Investigating and implementing evidence-based practices in schools. Journal of Multilingual Education Research, 6(1), 2.

Salend, J. Spencer (2011). Creating inclusive classrooms: effective and reflective practices 7. NewJersey: Pearson.

Sağıroğlu, N. (2006). Özel gereksinimli bireylere sahip ailelerin çocuklarının devam ettiği özel eğitim ve rehabilitasyon merkezlerinden beklentileri. Unpublished master dissertation. Abant İzzet Baysal Üniversitesi, Sosyal Bilimler Enstitüsü, Bolu.

Sarı, H., Atbaşı, Z., \& Çitil, M. (2017). Özel eğitim ve rehabilitasyon merkezlerinde görev yapan öğretmenlerin aile eğitimi konusundaki yeterliliklerinin belirlenmesi. Kırşehir Ĕ̈itim Fakültesi Dergisi, 18(3), 668-684.

Sivrikaya, T., \& Yıkmış, A. (2016). Özel eğitim sınıflarında görev yapan özel eğitim mezunu olan ve olmayan öğretmenlerin öğretim süreciyle ilgili gereksinimleri. Abant İzet Baysal Üniversitesi Eğitim Fakültesi Dergisi, 16(4), 1984-2001.

Seggie, F. N. \& Bayyurt, Y., (Eds). (2015). Nitel araştirma yöntem, teknik, analiz ve yaklaşimlari. Ankara: Anı Yayıncılık. 
Stefano, M., \& Camicia S. P. (2018). Transnational Civic Education and Emergent Bilinguals in a Dual Language Setting. Educational Science, 8(3), 1-22.

Tiryakioğlu, Ö. (2009). Rehberlik ve araştirma merkezi müdürlerinin özel eğitim bölümünün sorunlarini algilamalari, Unpublished master dissertation. Abant İzzet Baysal Üniversitesi, Bolu

United Nations Educational, Scientific and Cultural Organization. (2009). Defining an inclusive education agenda: Reflections around the 48th session of the international conference on education. Geneva: UNESCO International Bureau of Education

UNESCO. (2009). Policy Guidelines on Inclusion in Education. Paris.

Villegas, M. (2019). Determining differences in bilingualism and learning disabilities. Community Engagement Student Work.

Yıkmış, A., \& Ozbey, F. Y. (2009). Otistik çocuğa sahip annelerin çocuklarinin devam ettiği rehabilitasyon merkezlerinden beklentilerinin ve önerilerinin belirlenmesi. International Online Journal of Educational Sciences, 1(1), 124-153.

Zigmond, N. (2003). Where Should Students with Disabilities Receive Special Education Sevices? Is one Place Better Than Another? The Journal of Special Education. 37 (3). 193-199.

Wah, L.L. (2010). Different strategies for embracing inclusive education: a snap shot of individual cases from three countries. International journal of special education, 3 , 98-109.

Weiss, S., Markowetz, R., \& Kiel, E. (2018). How to teach students with moderate and severe intellectual disabilities in inclusive and special education settings: Teachers' perspectives on skills, knowledge and attitudes. European Educational Research Journal, 17(6), 837-856. 